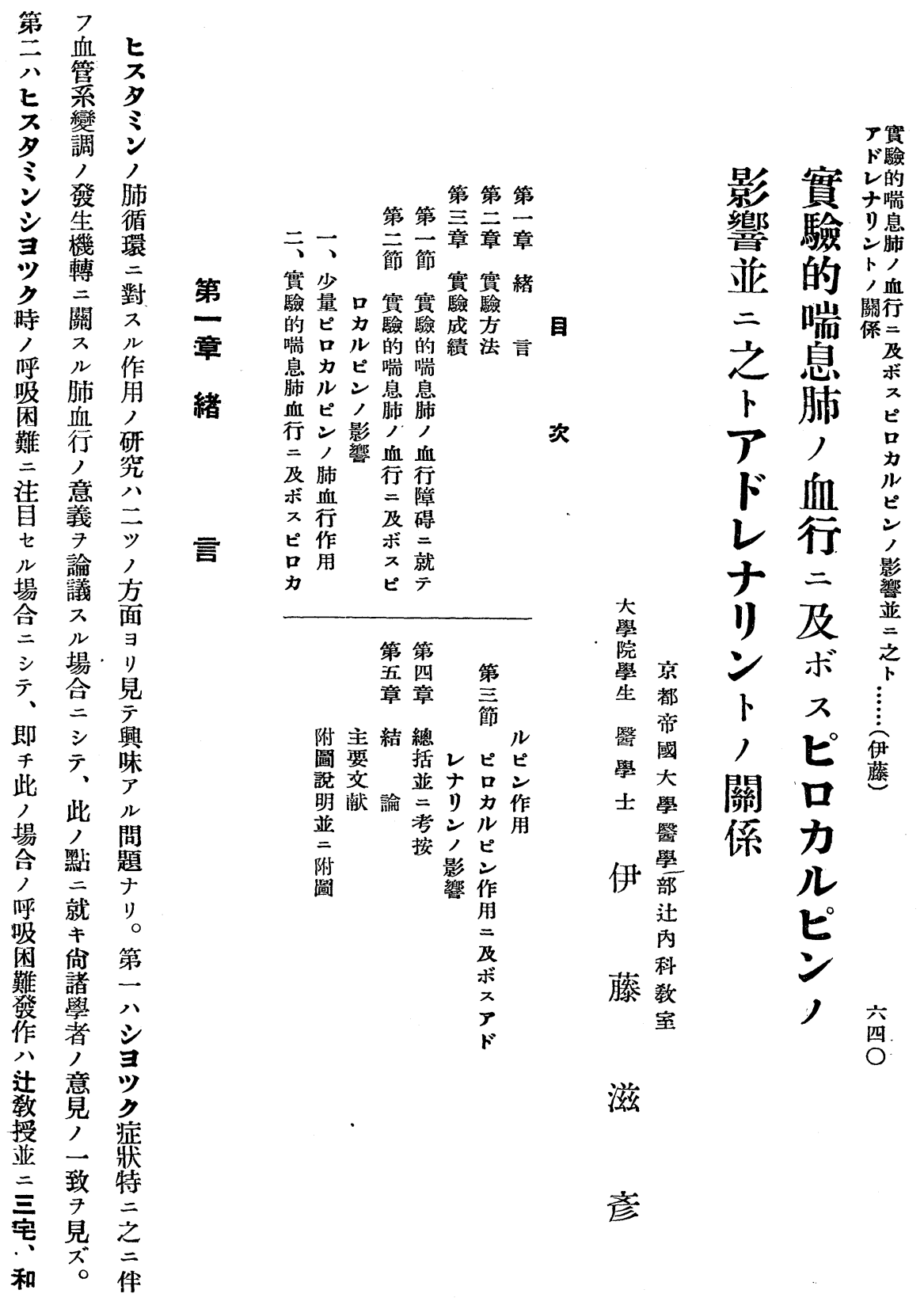




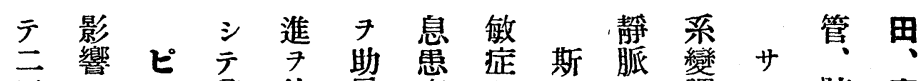

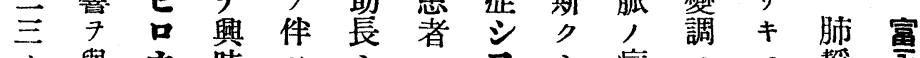

ア實

ド驗

V的

ナ喘

り息

肺

孟

關行

㛊二

มำ

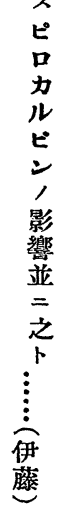

六

四
, 與 カ 味

考

察ルビルル雼ゴク發八ス八等二

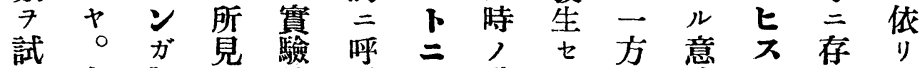
i 余斯ナ的吸 1 喘儿呼義夕有 夕八刀口喘困子息實吸公令儿其

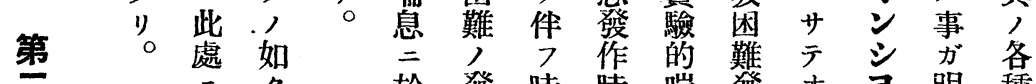

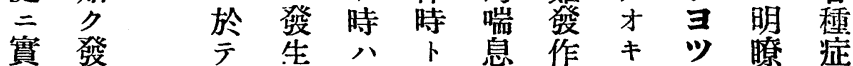
實登作要 動促篇り作發吸時七二

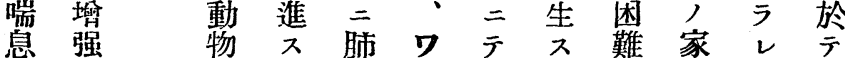
驗嘣

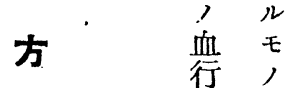
法障

碍 ス

เ゚

セ゚゙

カ

ピ 密

接

,

關 ル

係 關

亚 係

$\overline{\bar{x}}$

$\sum_{i} \sim$

$ア$ 肺

ド血

ᄂ 行

ナ障

》) 碍

$\nu=$

卜 對

) シ

相 テ

關 如

關 如

倸 何

就
像モ細、喘卜作脑当

× 血二息同卜䛻り枝

ピナ管 I患時相環初喘

口儿, 並者二伴 $尹$ 息

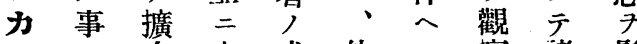
几八大笑或他几祭諸髮

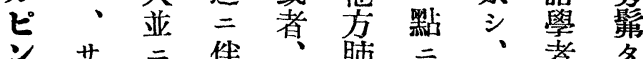
キ 市华及循洼常者 投二射生 ビ環自二注 シ 教氮變占障・血 $\ni$ 的 才授管調同碍七行㬇モ ク二枝 $尹$ 一

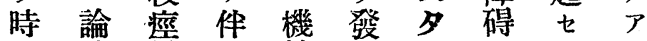

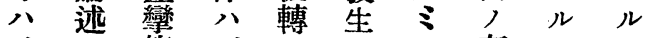
、等 ザ 發亏, ル依ル二在, 指 作 レ 發 モ 子夕生, テ, ルルリ七 促 $=ナ$ 發卜肺

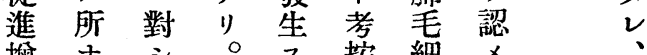
䔣ナシ。按細 强ル、然ル七血 タ スガ副蔴トり管ル ル、㽬藤信

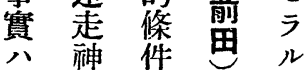
之經 占繁 三 般 血 關㲀 $\bar{二}$ 清 聯䓵之喘過
擴

粱 栄

盖 全

並 身

二 血 肺 管 與过性體之方肺意么 事迷的前ゼ
主

恶

化

肺

毛

細 
先䟼更呼濃紪主サ

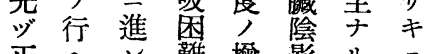

政へデ䌣墂影特所余

時。力作肺動其見

於 公

環 宁擴 坐頸 喘

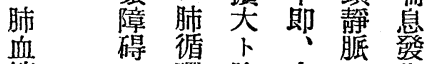

管儌琣右作

型間的濃 室窒 的

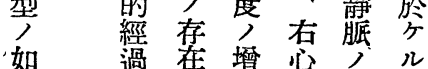

名不强房擴肺

撮明

七二確自尔陰像

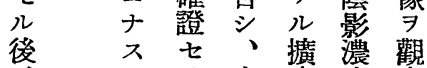

約 ヴリ学大度察

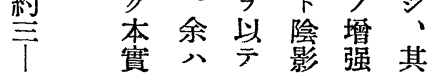

量相公觀 7 終女五

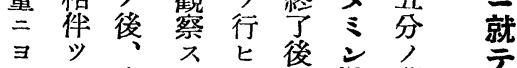

产突 $九$ 夕貁間

テ著如 云り。分液隔

長奛占 凡远学

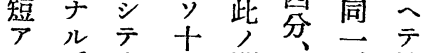

、呼定五間七再造

二性犁梨家, 分静影

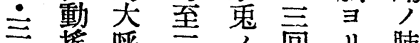

分摇呼主分回 金肺

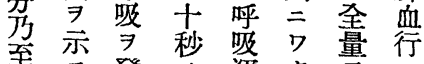

至不發, 運夕量沓

七。生 $二$ 動 リ 約 y

分其方過 寻同立流

二呼肪無廓條秒

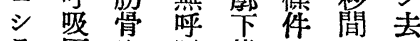

テ困管吸線 $\Rightarrow=$

次雖市或, 以注 7

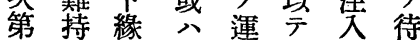

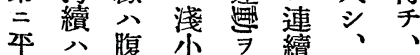

静注壁呼 以撮集 ヒ

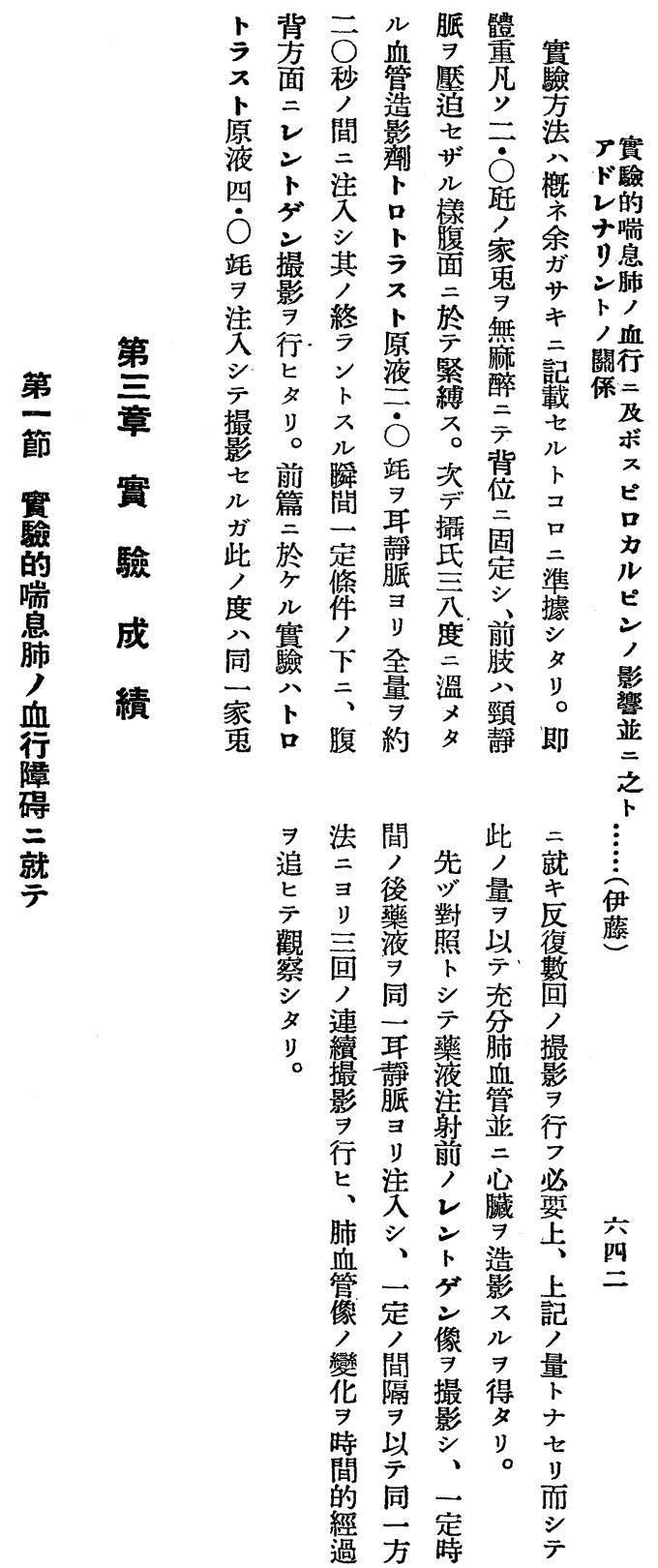




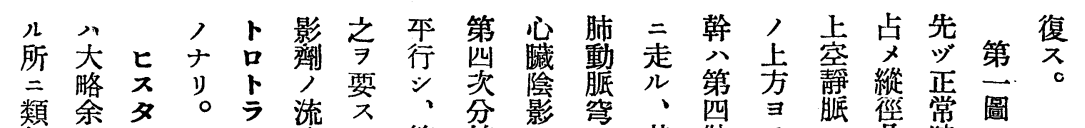

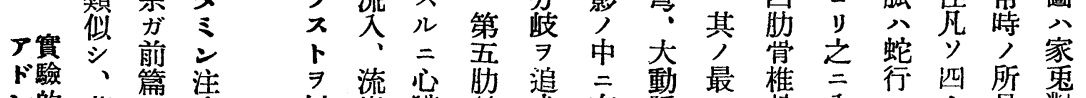

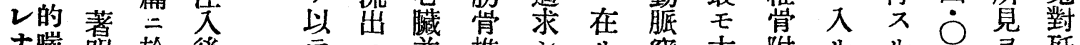

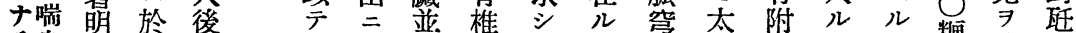

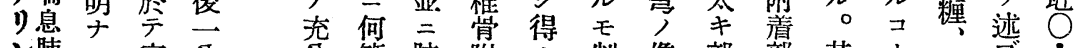

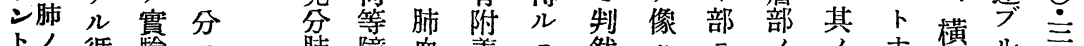

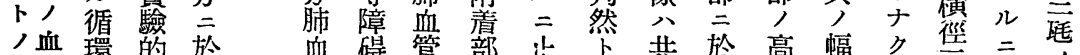

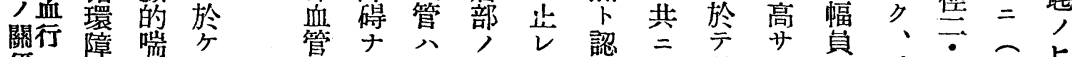

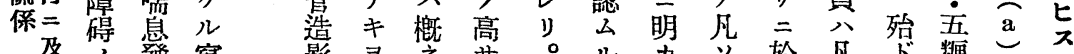

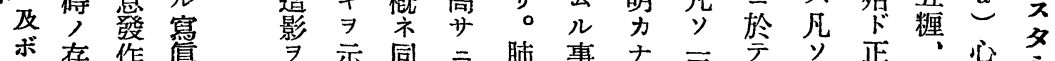

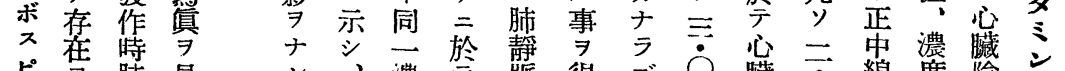

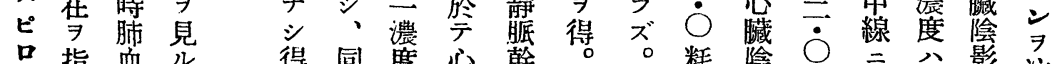

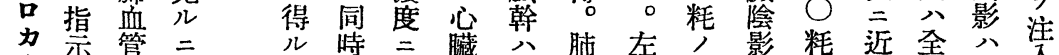

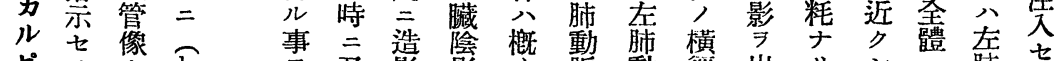
ピ リ

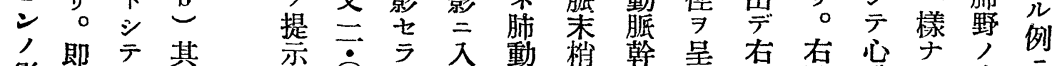
影即テ其示

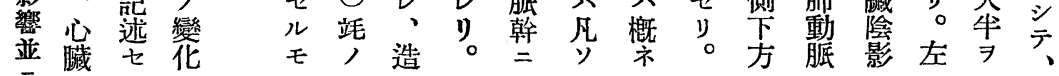
之

$\vdots$
$\vdots$ 有 ナ

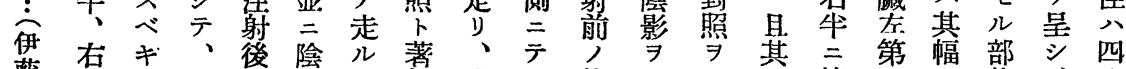

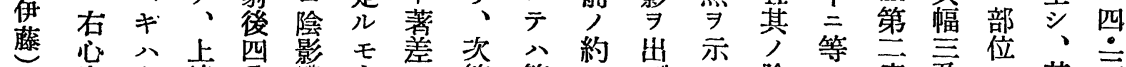

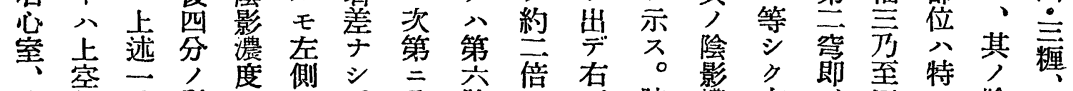

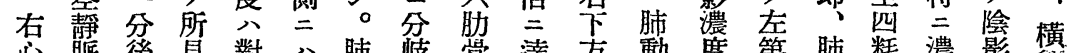

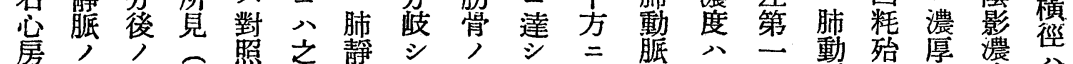
二擴所 c

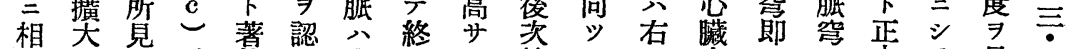

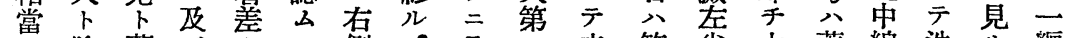

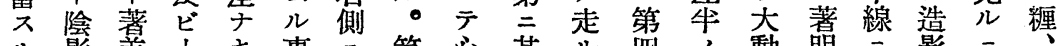

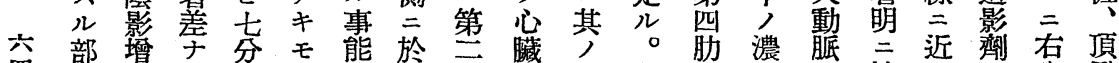

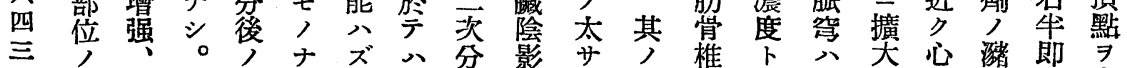

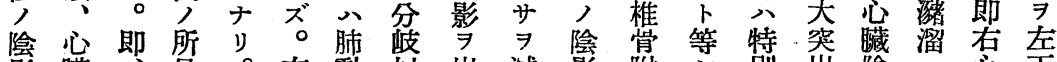

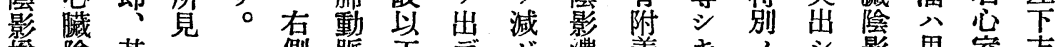

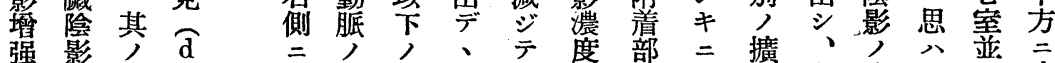

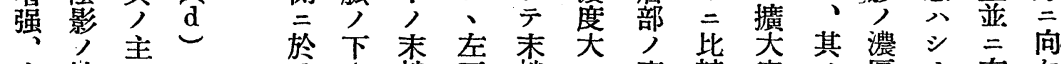
左擴主八方梢卡梢二高較突分厚么右尔

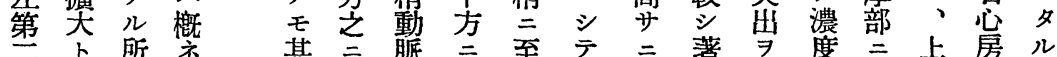
䆓其䙿同 其市脈向至幅

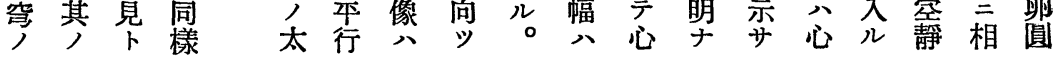




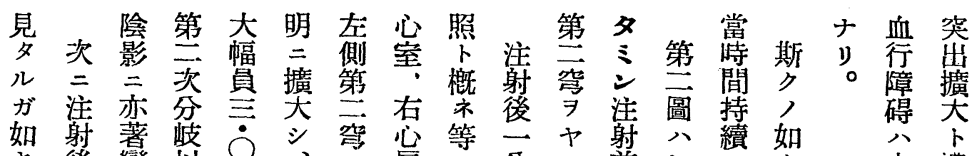

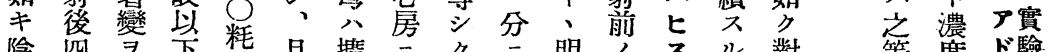

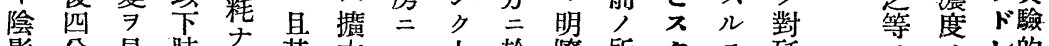

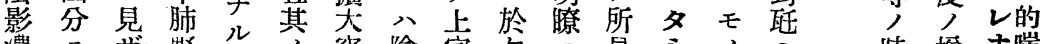

䕃

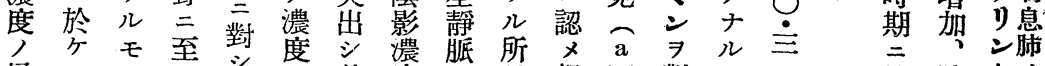

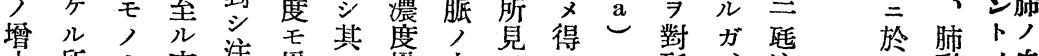

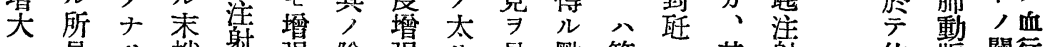

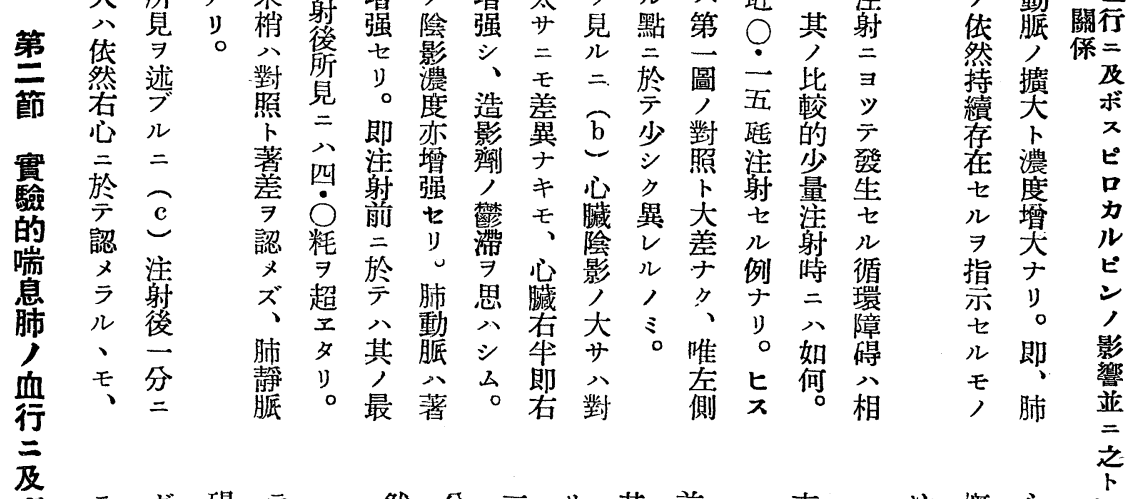

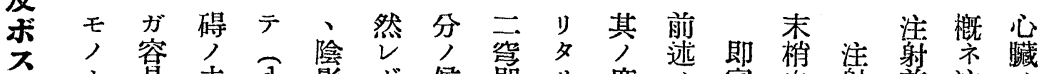

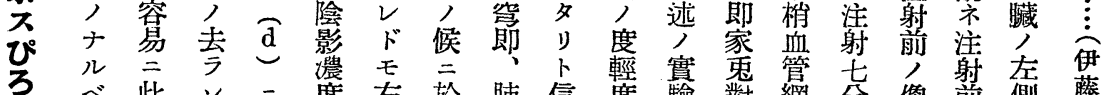

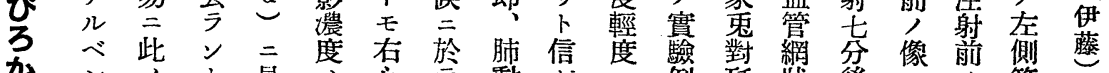

加

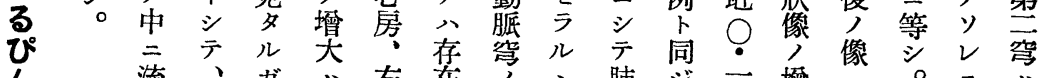

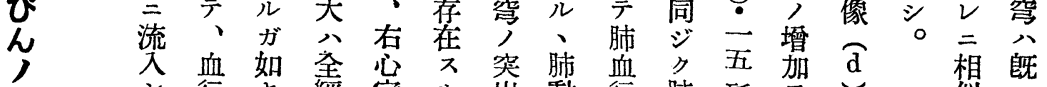

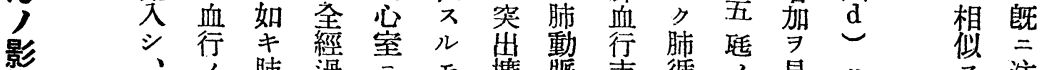

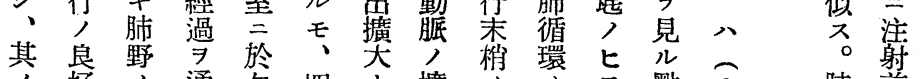

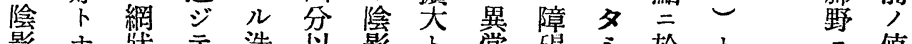

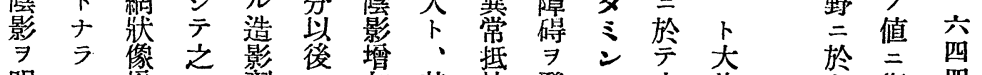

明

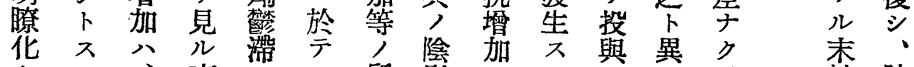

七几、事, 八所影三儿空之、梢肺

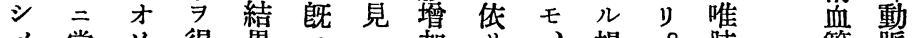

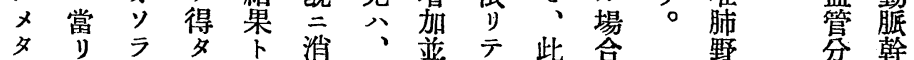

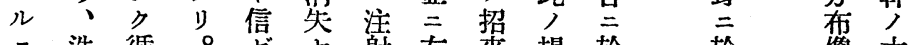

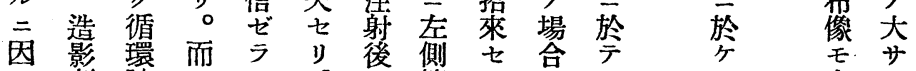

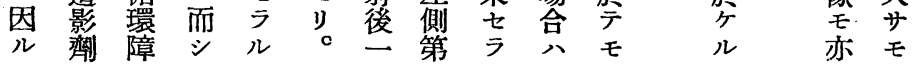




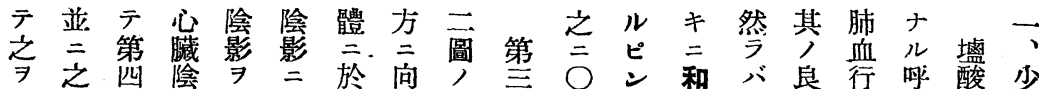

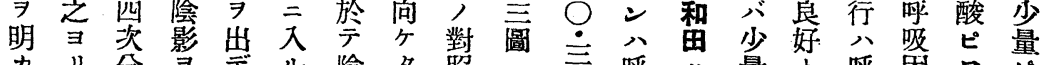
ア惯 ド驗認七

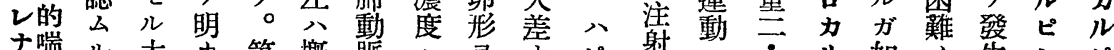

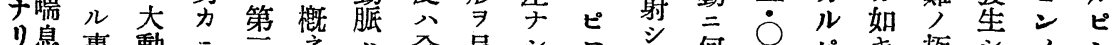

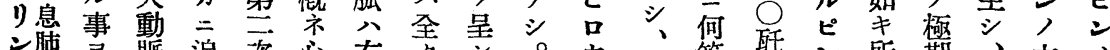

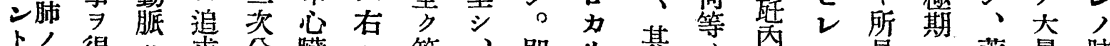

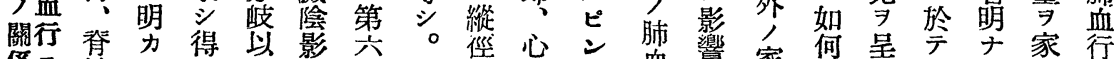

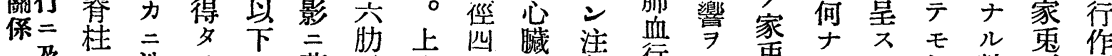

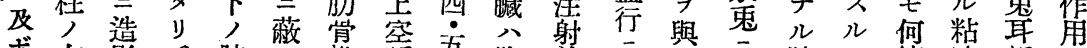

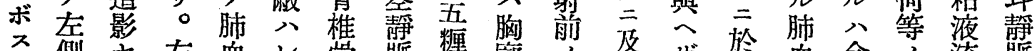

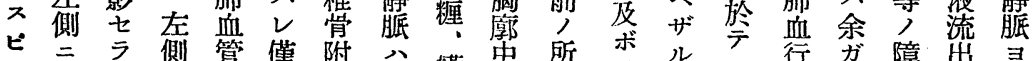

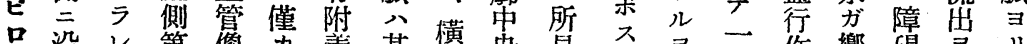

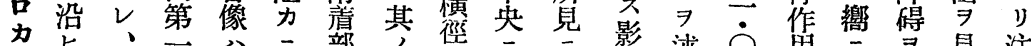

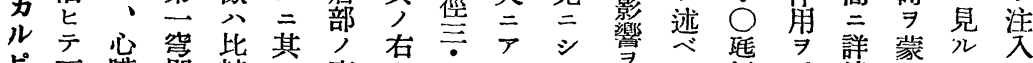
ピ下臟即較ノ高上三リテ

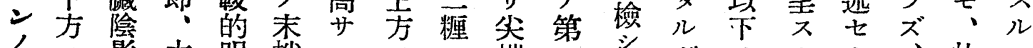
影向影夸動膫

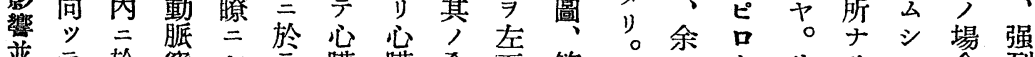

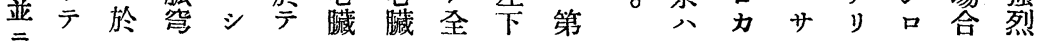
点

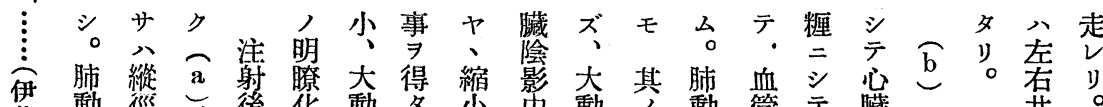

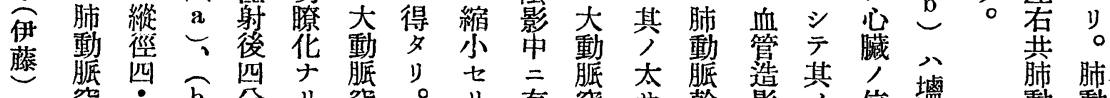

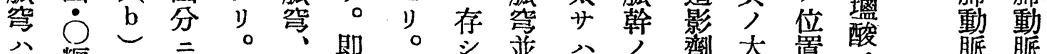

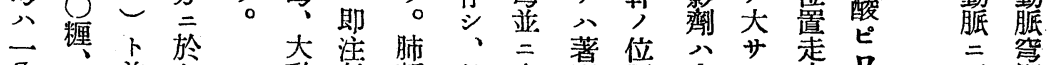

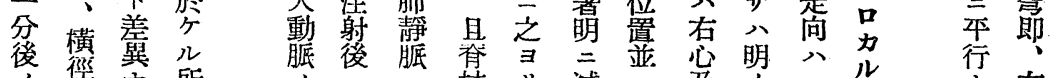

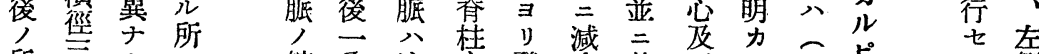

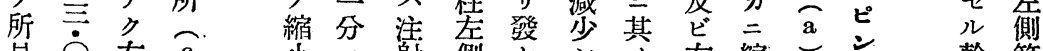

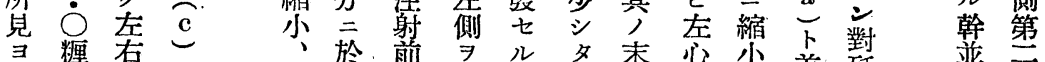

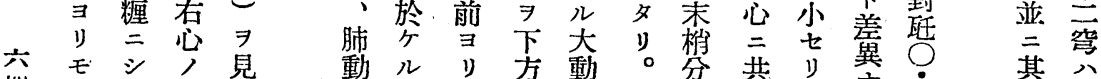

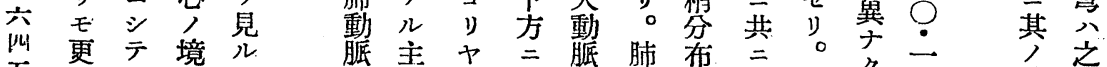

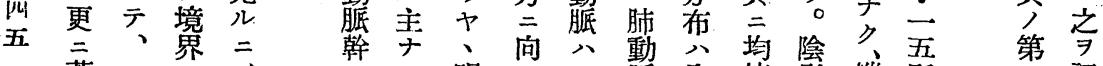

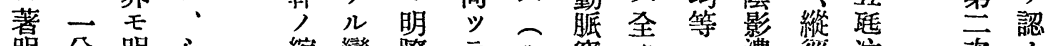
奛分明心縮變瞭 $匚$ a 穹 二後力贜 小化二走 一公二混度四射分n

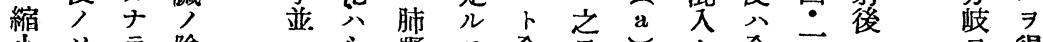

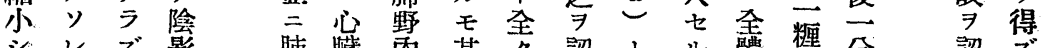

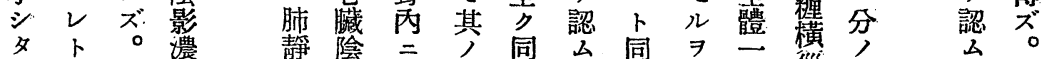

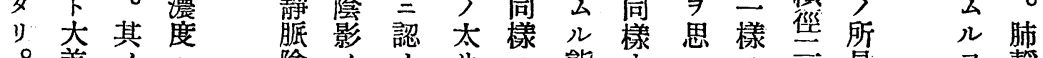
但差大全 险縮 ル 


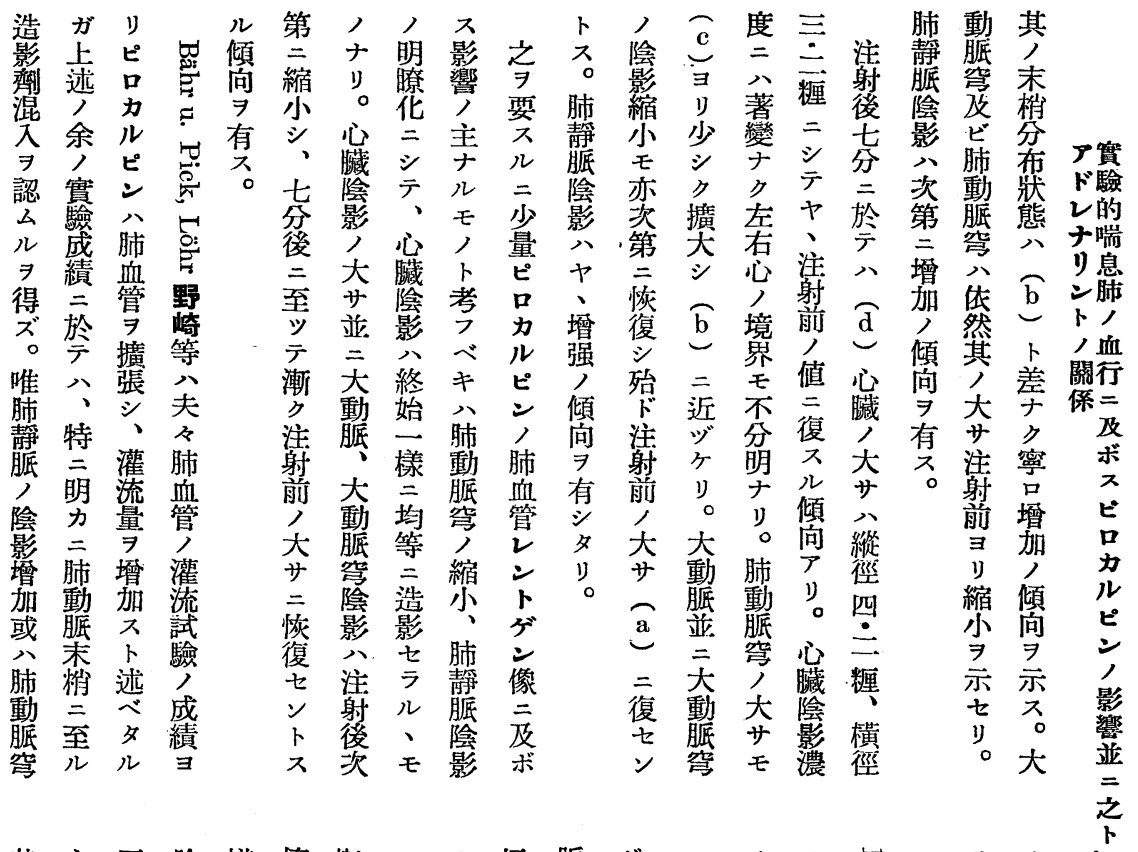

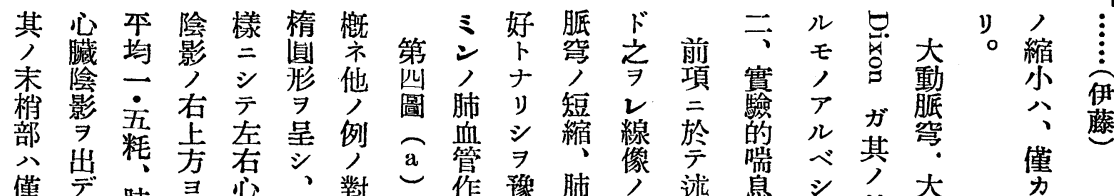

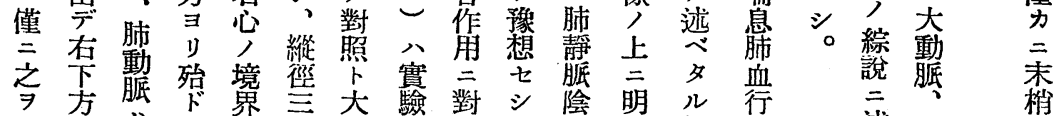

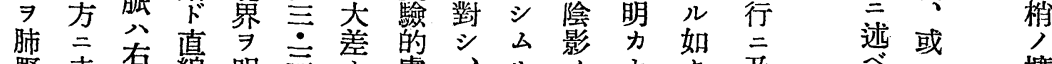

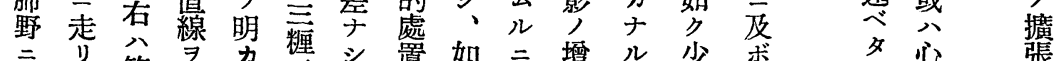

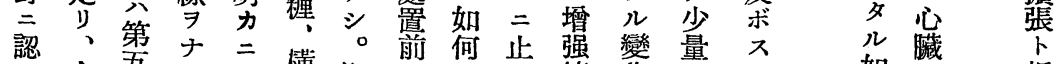

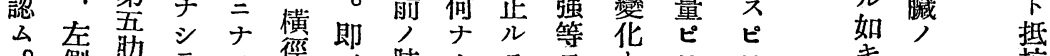

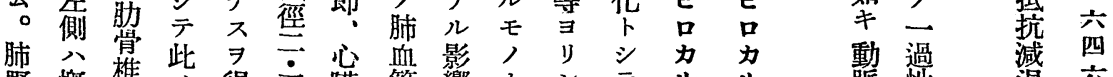

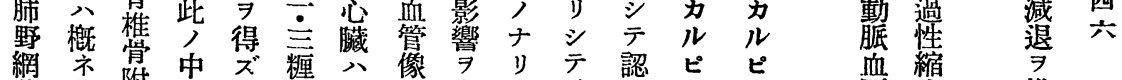

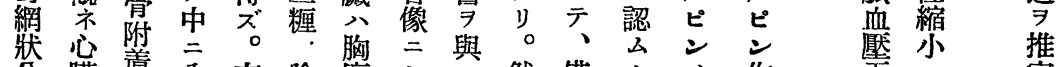

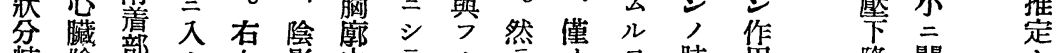

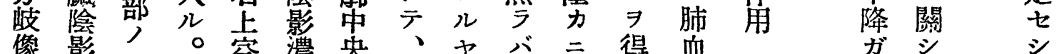

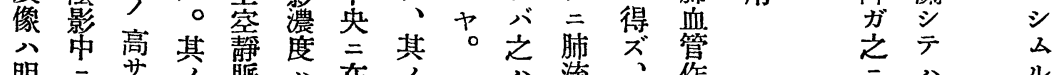

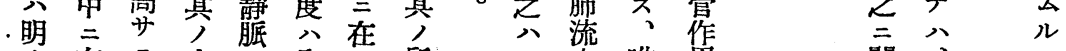

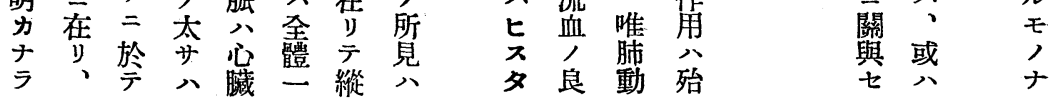




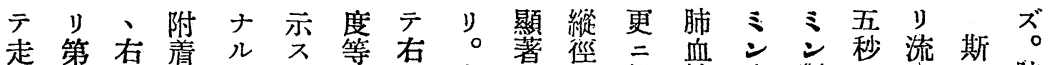

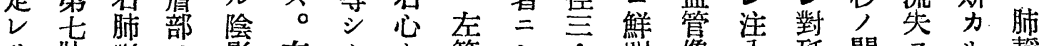

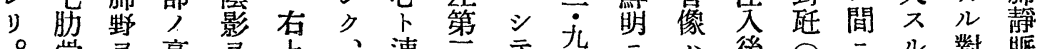
實左 学

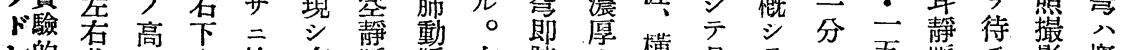

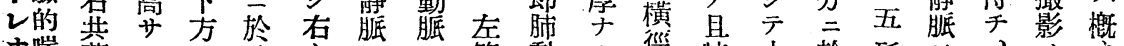

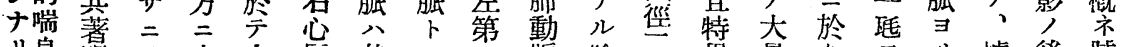

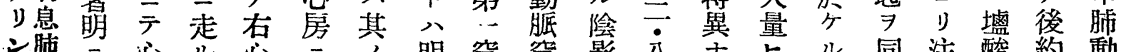

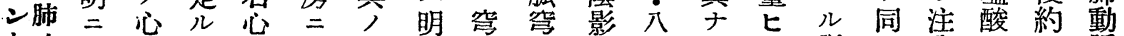

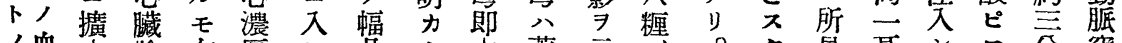

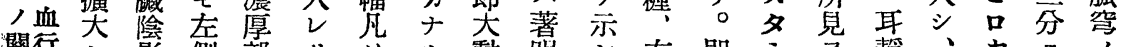

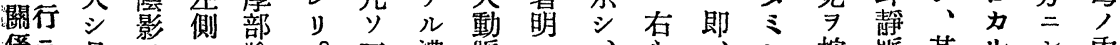

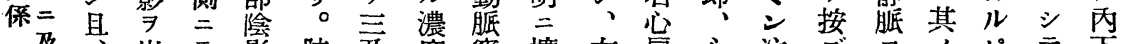

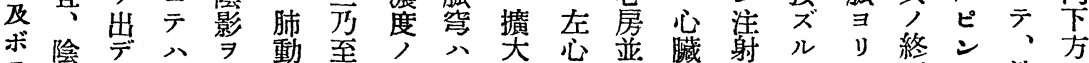
ス影、 左出质 四差概

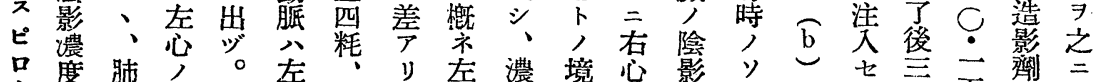
力度野淡右右右

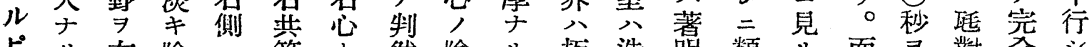

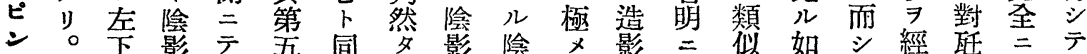

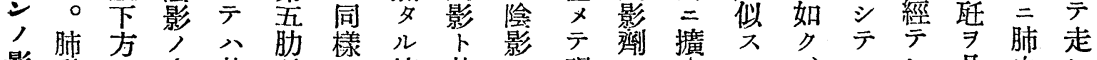

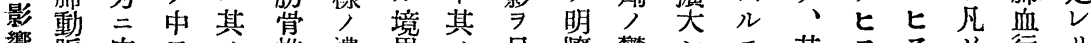

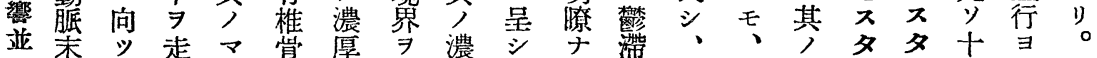
之

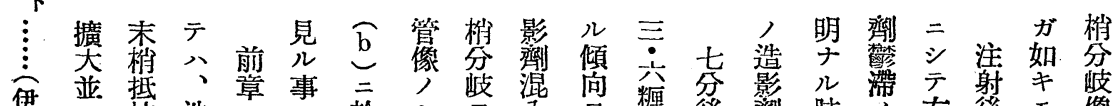

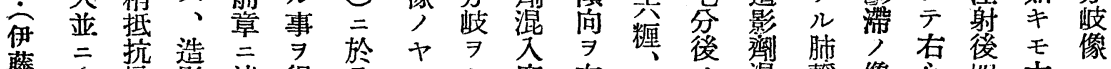

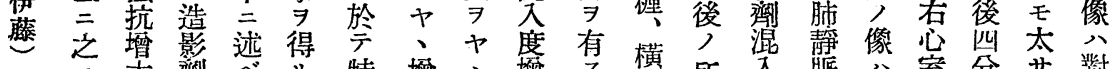
關

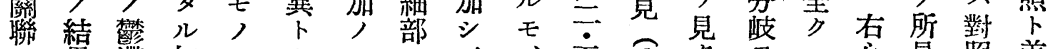
七果滞如ナ 七傾三:、主 $\mathrm{d}$ 多

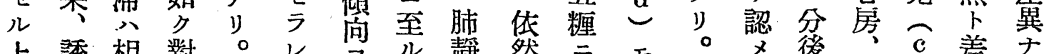

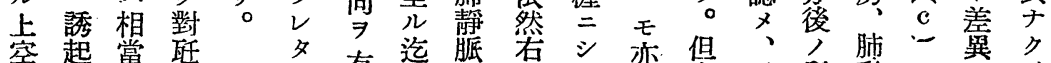

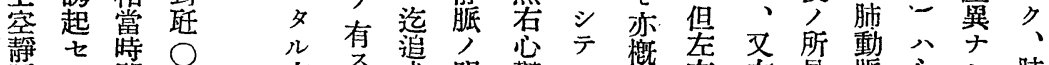

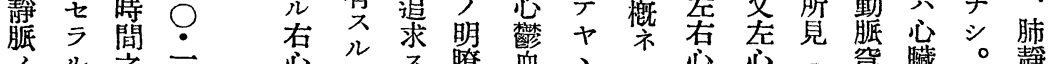

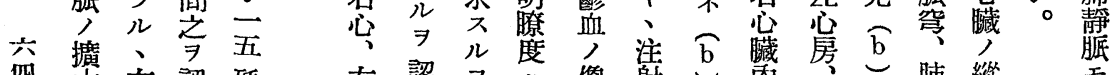

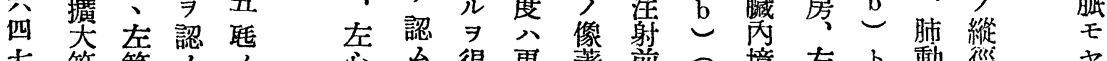

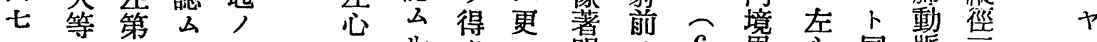

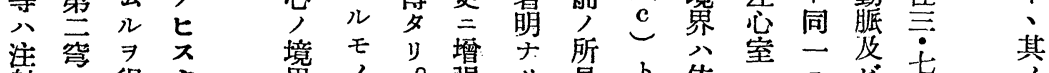

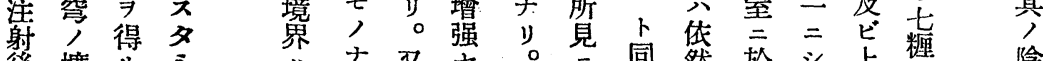

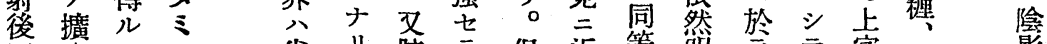

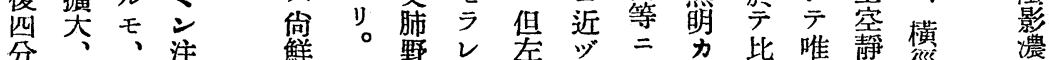

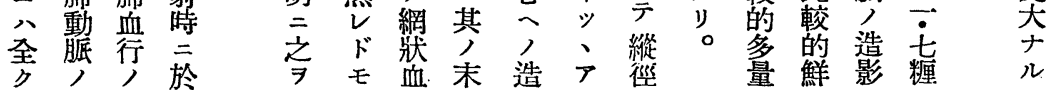


分公椞 7 望注影投

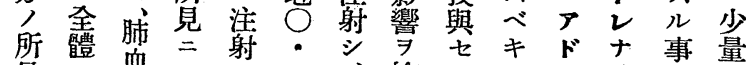

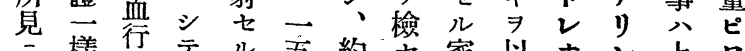

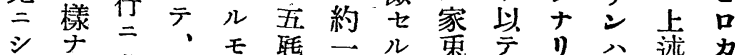

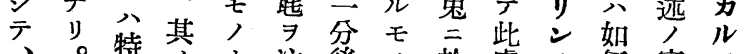

心・古記變り㴬撮ナ方處公何實ピ

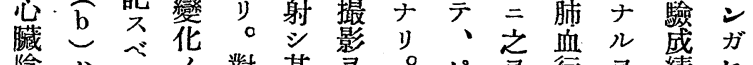

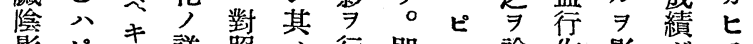

影 ピキ 詳照人行即口論作影永ス

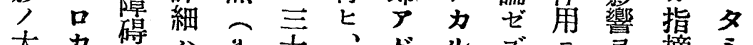

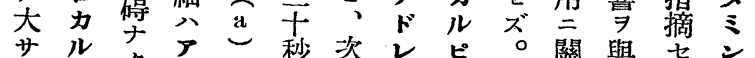

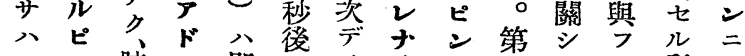

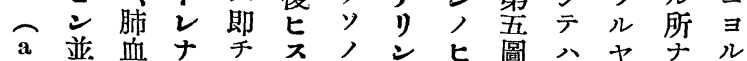

管り ア タ

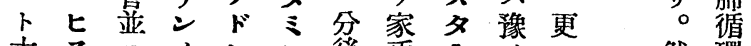

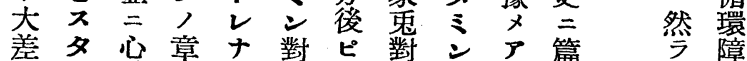

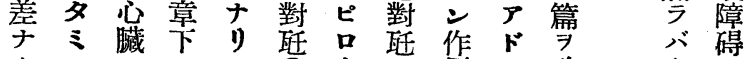

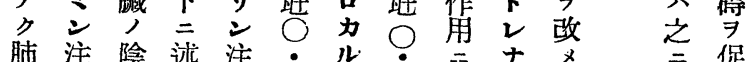

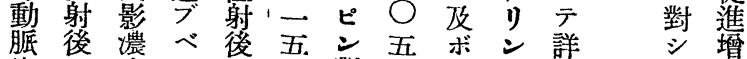

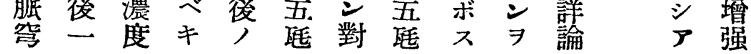

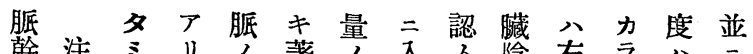

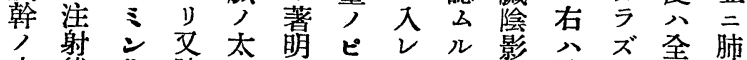
大後作肺サ品り事第從體動 サ四用動八儿口。 及分八脤七肺ル肺得デ助左樣幹 濃 さ 度並些擴令, 及所空罂左心学 公處笑障 ビ見靜方公人、シ 共 爷 $三$ 注碍 七公脈二第境特、

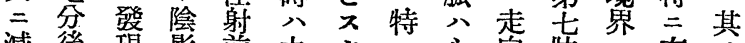
减後現影前之夕三向肋公右了

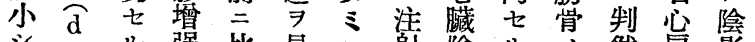

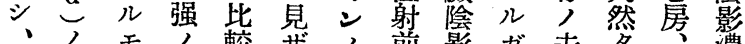

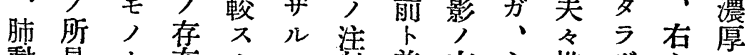
動見卜在ルモ射差右心椎ザ心ナ 脈公認ス二ノ=異上臟学ル至り

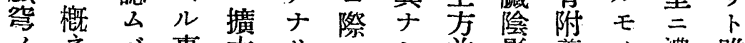

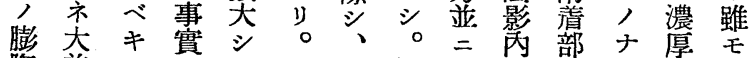

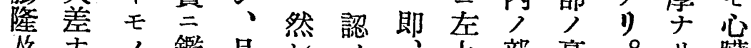
及于

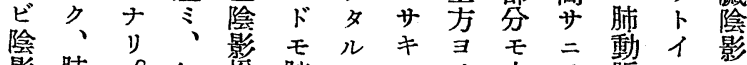

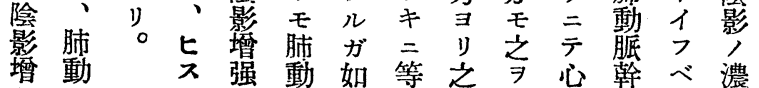

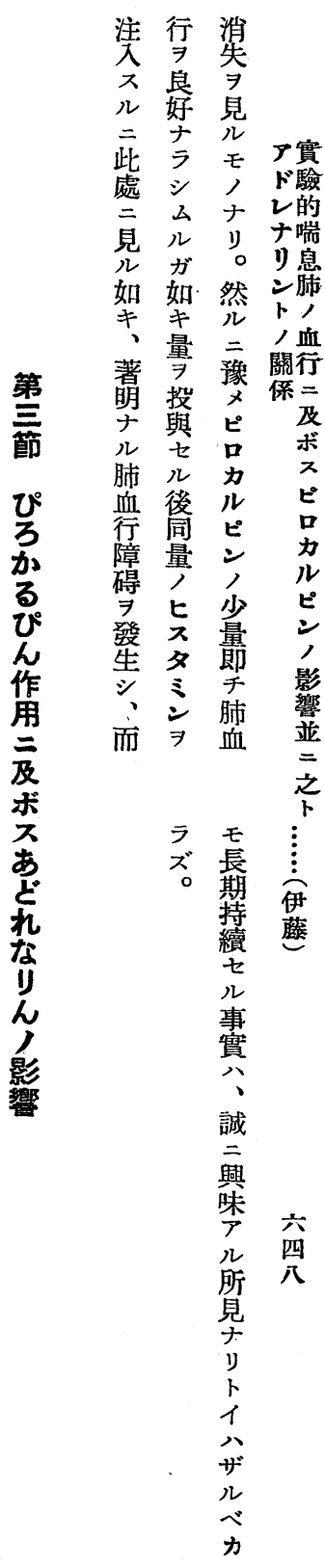


夕メ ル 这測何觉碍關

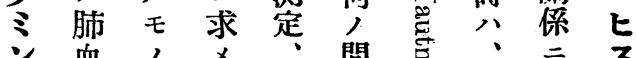
キ 血 ナ メ

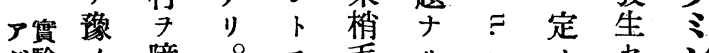

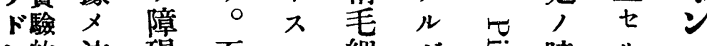
乙的注碍而ル細吕命時ル二 ナ喘射 ス $シ$ 血之間モ り息シ $ン$ 對管三ト的ノル ン肺、バ之シ人關つ持ナ肺 卜血次、手、觀聯 論續儿:血 關行 デア 論 $\Omega$ 祭 シ 爭

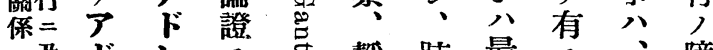
及ドレス究静肺最ス、障 ボレナざ脈阻近余得 スナりキ血歨注事方が

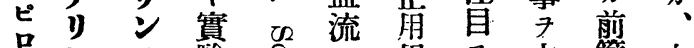

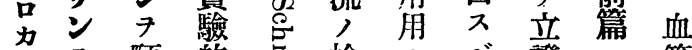

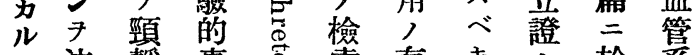

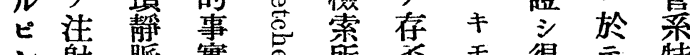

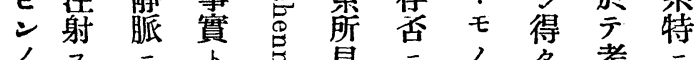
影ル 注 シ 总学關 こ

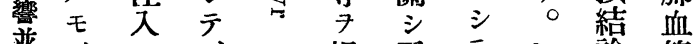
之動 ル 炭之拫再 テ、ヒ 論 管

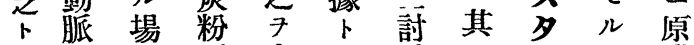

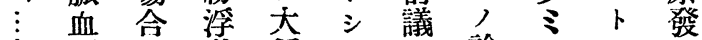

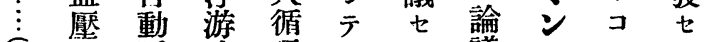
伊上脈花環、 ラ議, 口儿 藤皇血 $尹$ 二頸レ血ナ變 三壓 動 求 動 タ 焦管 几 化

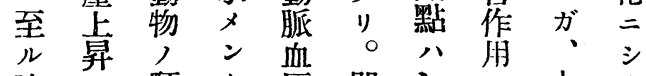

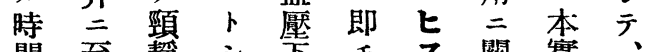

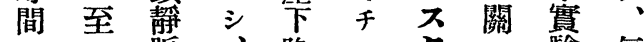

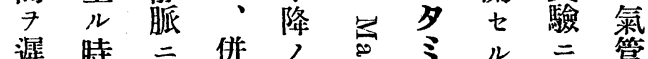

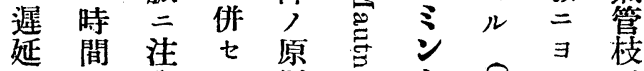

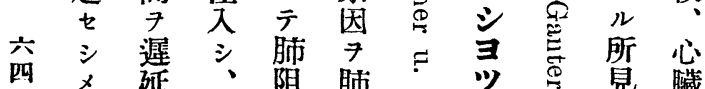

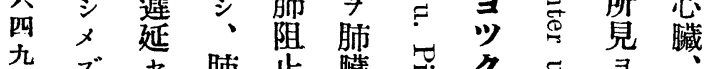

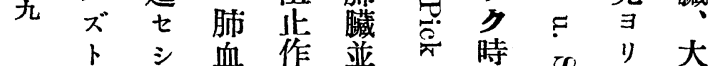
， 厶管 用 三, 實 ル 栓ノ旰灌血市テ環

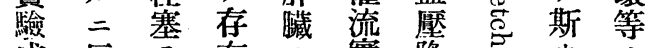

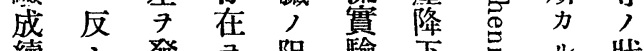
續 三 發 7 阻驗下志儿狀

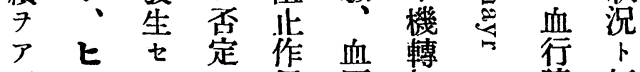
ゲスシ 角壓如卜障無
注市次り 尛 テ ピ 其カドレ゙之 影ピナ兵認 響さンリ右㥖 見注, 見㴬少於 事 二 シ 量 合 得 第 第 其對 輕 ズ 四㴭然度心 草圖市官险藏

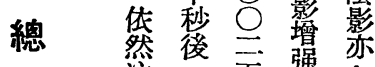
括 注吾强ヤ

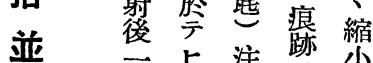
二 分王射步 少 考四只长向 按 $\begin{aligned} & \text { 分 } \\ & \text { y }\end{aligned}$

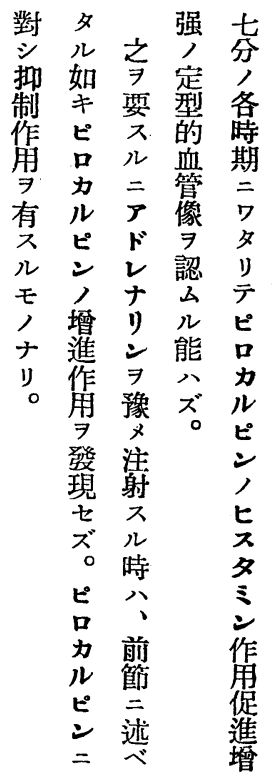




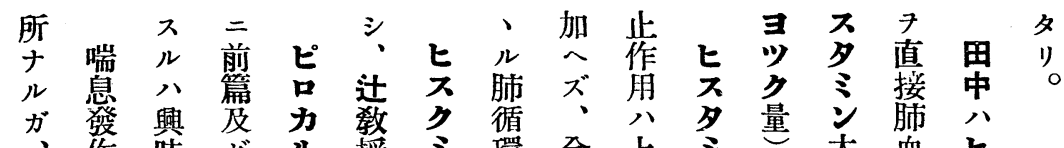

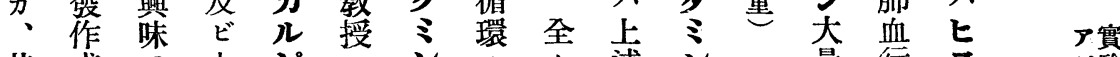

其或

人 ル篇 シ 喘 八障自,

作實知

用驗見余肺學クガノ, ル肺二ルンシ 息

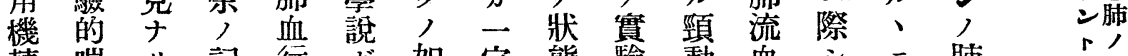

轉 喘り記行 ガ 如定態噞 動 血 シ 二 肺

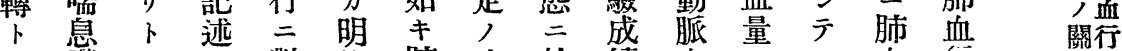

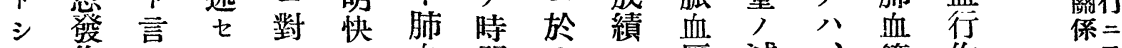

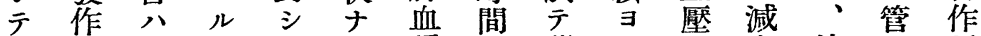

舉, ザ 實輕ル行的藥り下少迬, 用

ゲ呼儿驗度解 持物 三降 7 射收 7

ラ吸さ成, 說 障續作テ、ガ大後 縮 觀

ᄂ困力䋶擴 7 碍 $尹$ 用、如循 $\rightarrow$ 察

夕難 $ラ 、$ 張 與 $尹$ 有 7 疑何環過見

ルニズリ作 フ 發 ス 觀間子二性ルル

卜對。見用儿生儿祭, $儿$ 於, $一=$

コ $三 7$ 事

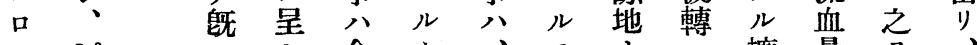

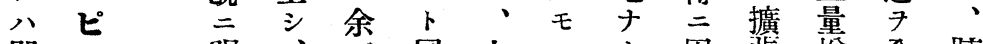

即吕明、分同上, 卡因張檞全肺

千カ 力肺劣時記ナ事由三加身血

其ル ナ血 $キ ニ$ レ 實

ピリ行三他實バ三ルシ 見行並

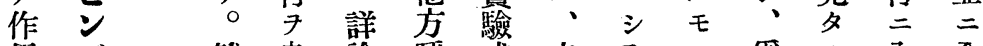

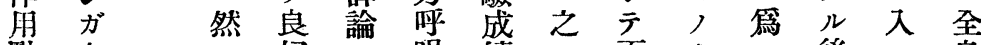

點之心好 七吸績三而ナ後 公身

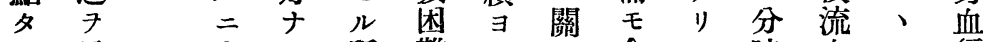

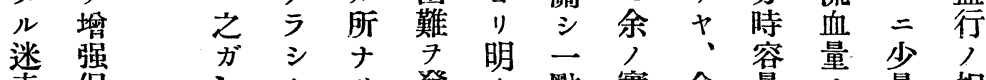

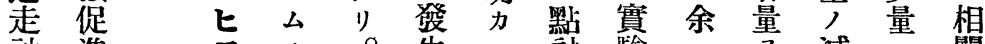

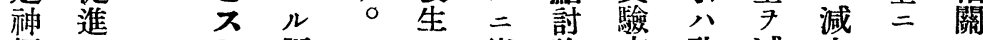

經 ス 傾指論方敢減少テ令

末 令向摘, 法テ少

梢八 $八 7$ 而七餘八此

共肺有 シ

介キ血 ス テレナ動二三リ肺析

シ 二 行 ル 此夕キ物之至。流考

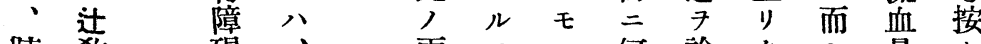

兩モ, 何論タ シ 量 七

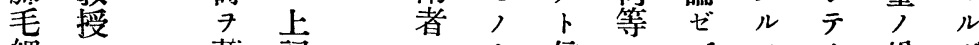

細三著記志ナ信, ズモカ增が

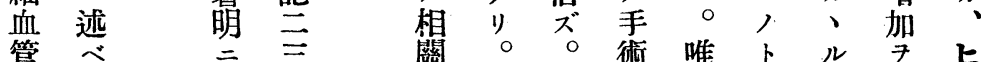

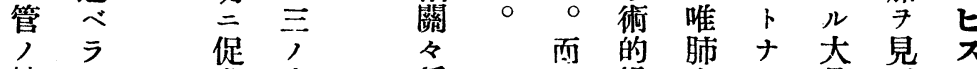

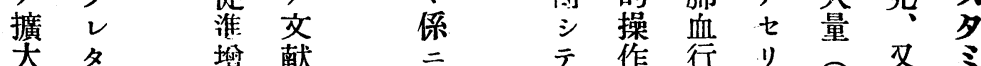

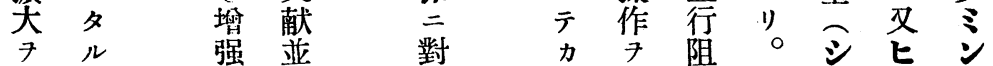




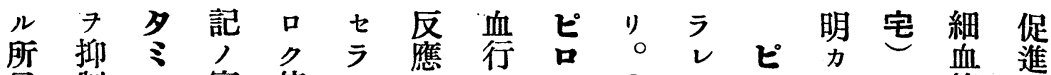

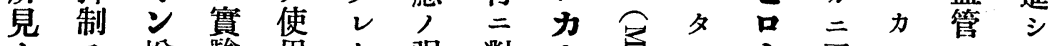

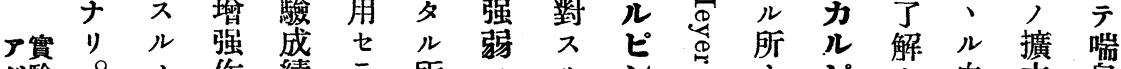
ト驗 ○ノ作績ラ所ハルンテナピセ血大息 レ的事用 $=$ ナ ア 作,

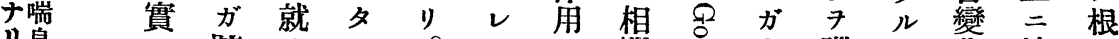

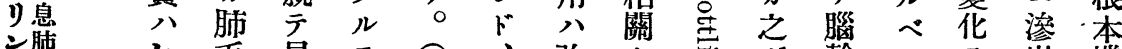

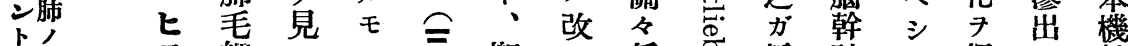
, 血細ルノ宅概 メ 係 す 靜神。促八轉 關行夕血二ナ宅泉テ分七脈經 進同夕 保= 管、只 及

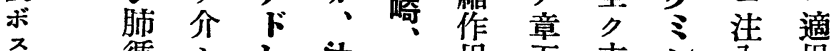
ピ 循シ レ 过柿用下禾ン 入角

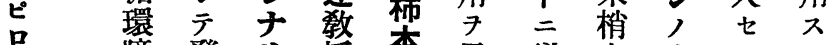
カ障發り授本呈䛨血血 ル 碍 現 ンニ 西 ス 論 管 管 レ 時 ピ ン 對ルピレ茾モざ於角ルル・ 影 シ 對 カ 其

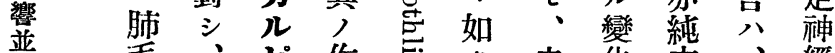
並毛、 ピ作吉吕之化策、經 之細 肺ン用之肺心二梢其中 衁毛, 機点血原性方楛 管 䋘七轉 总管身發ノ作並

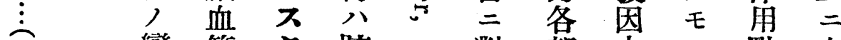
伊變 管 夕肺武對部间, 點血

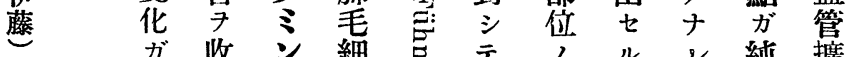
ガ有 縮 增 血 ス 七强管 モ 其 管, ○梢 神 ル 作, 分 二 意么用擴 克於考宅ナ中 䉝 ル

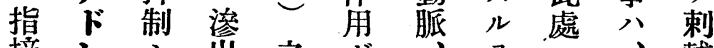
六 摘 レ 五. ルリリ抑古縮細心゙ラ般ル 點 ン

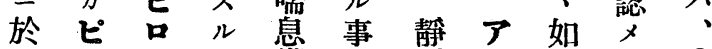

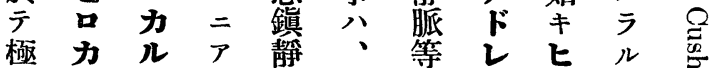

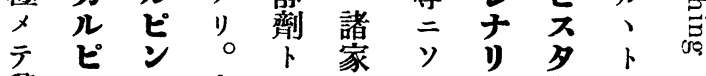
興作とと $ア$ 用 ス上七䜅レ肺卜ナ卡

シ 時 ル

乎 存 昁 吸 ス 細 困ル血 難 肺 管 助脈擴 長 㽷 大 ス變卜 ルト贸 七゚ 相 出 口 俟 7 カ ルテ、長 ピ、政 カ文伊 他 不 方 少 飞 : 示 夕肺 的 循 氣 $ン$ 環 管 了障枝 肺第碍 㽷 血了攣 行原子 障因促 碍 7 ス ナナ = 助 長モり ルナカ ᄀᄂ 、 事バル 實三斾 


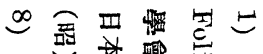

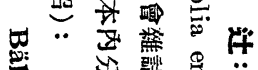

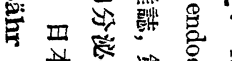

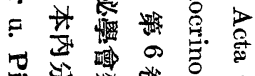

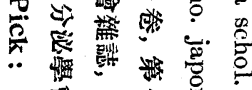

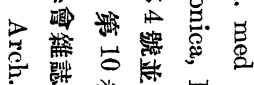

फ 牙

星 or or or

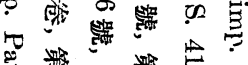

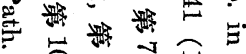

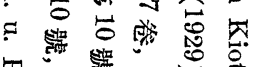

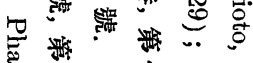

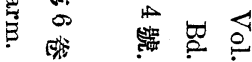

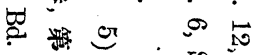

年 $N \rightarrow$ T

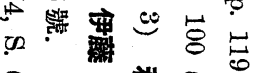

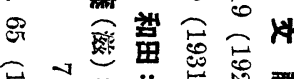

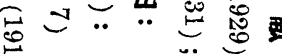

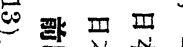

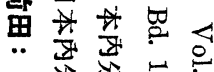

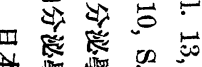

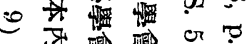

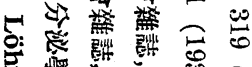

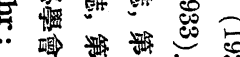

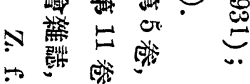

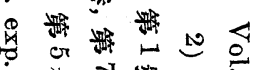

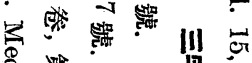

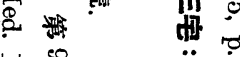

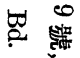

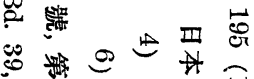

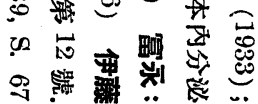

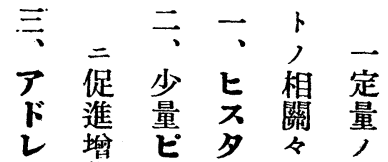

本師筆 し 翋 ビ タ

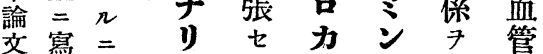

要道當ンラル烀檢造

旨撮リ八ルピ吸索影

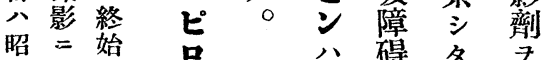

和際懇

十篤

一御 ナ

年助儿

三力御

月、指

第

十七 御

回 $n$ 校

日木閔

本 崎 7

內 學 賜

分士

泌並夕

學 =

會金恩

總 澤 師

會比茫

席三数

二进 $=$

於子梁

佂謝

之謝 シ

報意併

告表

七 $\pi \bar{T}$

リ○御

口八碍夕夕

カ 正即少用

ル 常 千 0 七

ピ肺 實

ノ 血 驗

七 $\quad$ 喘

ス 輕 息

夕度 時

令 發

肺好 生

血行 ナ

障柿

碍

ム 血

助長毛障

作、碍

用

抑

制

之

7 相

㐨 當

テ

奣

血

撮

撮

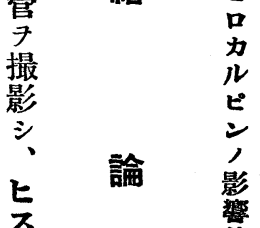

E

족

夕

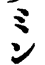

第留血

五 保二

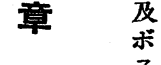

結 ピ

並

学

注時

射間

不的

ル 持

時 續

八 7 ヒ⿺

七有

ス ス

y

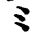

之

之

及

ボ

ス

影

稺

r

L

ピ

賜

夕

$n$

宅

講

的

水

カ

六

五.

肺

血

障

碍<smiles>C#CCCC</smiles>

ピ =

並

$\bar{r}$

F゙

藷

ᄂ 


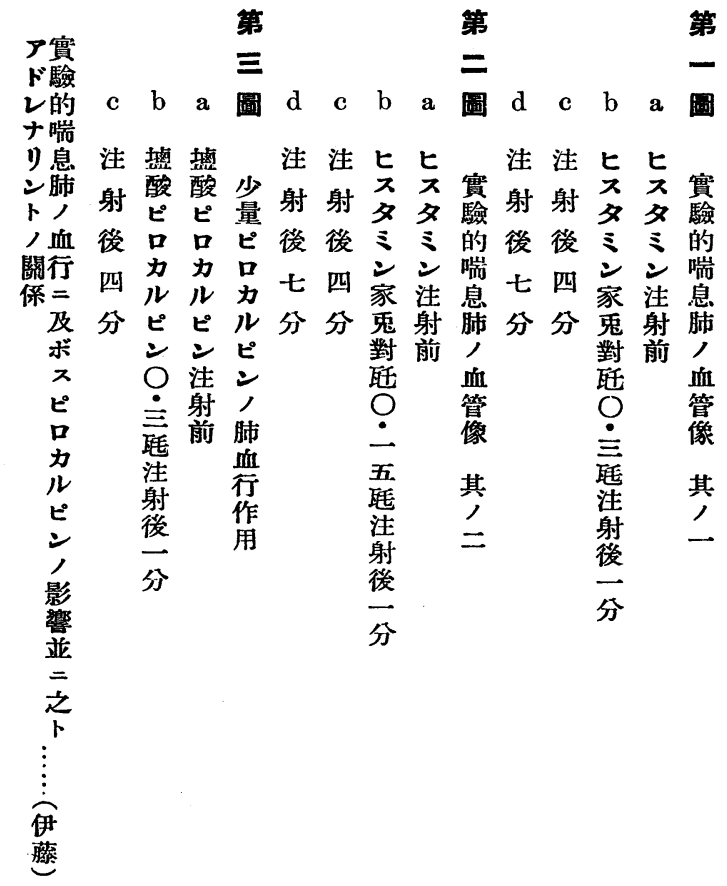

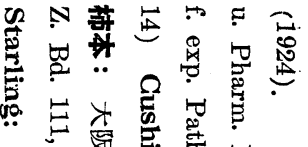

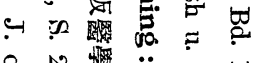

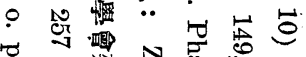

总瓷唧

附? ? 它它皆

圖

說 今

明

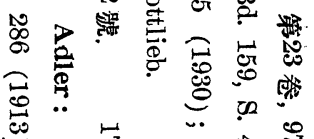

豆

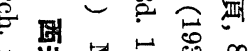

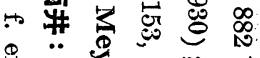

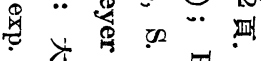

10 迹 $\div \frac{10}{2}$

亲

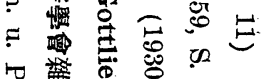

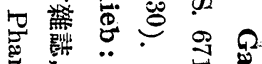

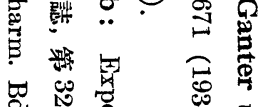

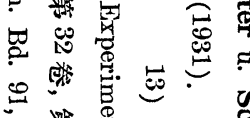

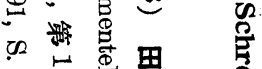

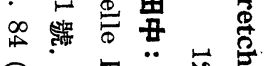

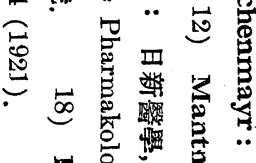

五

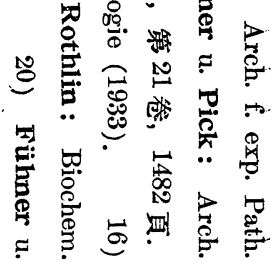




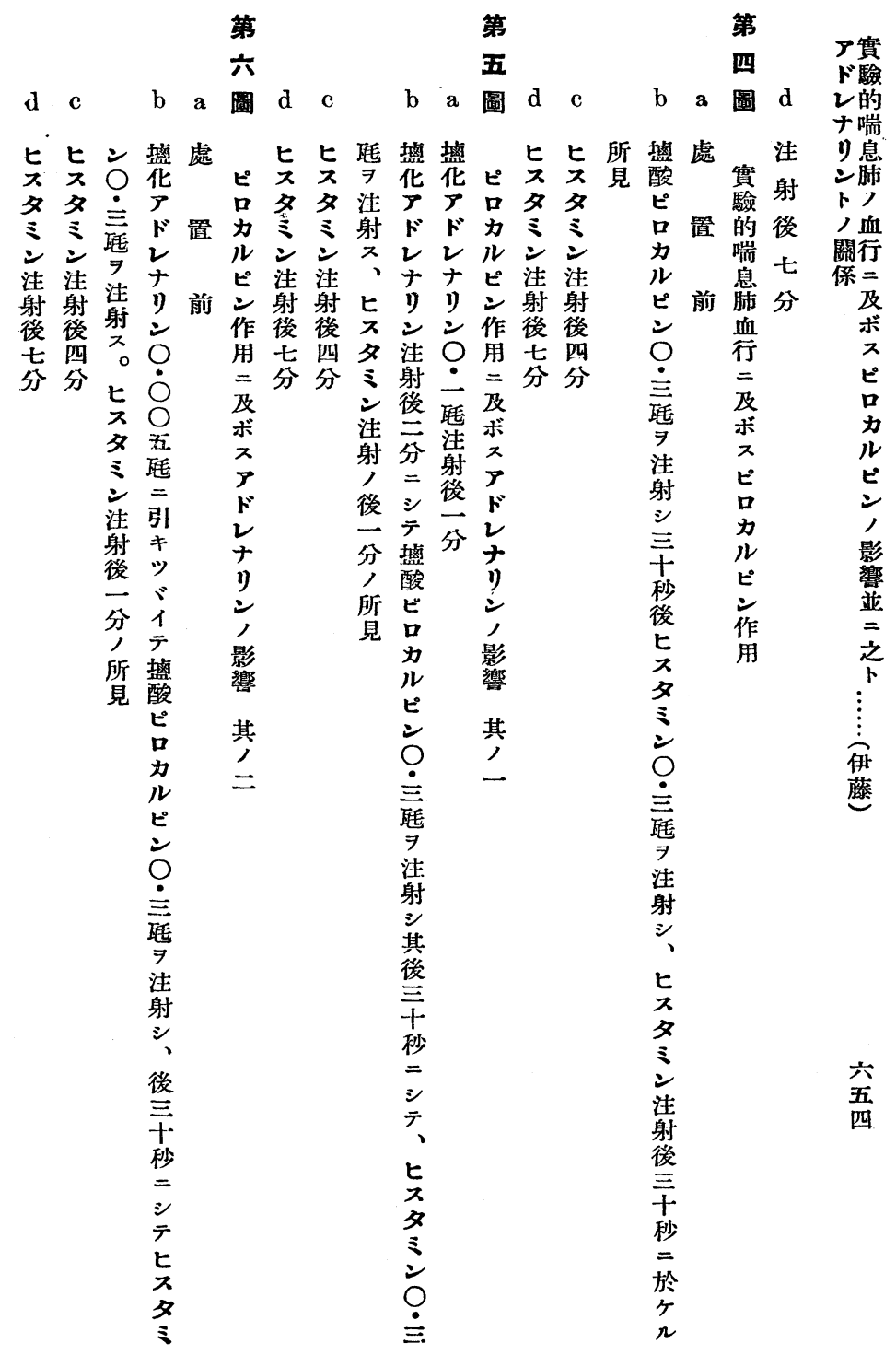




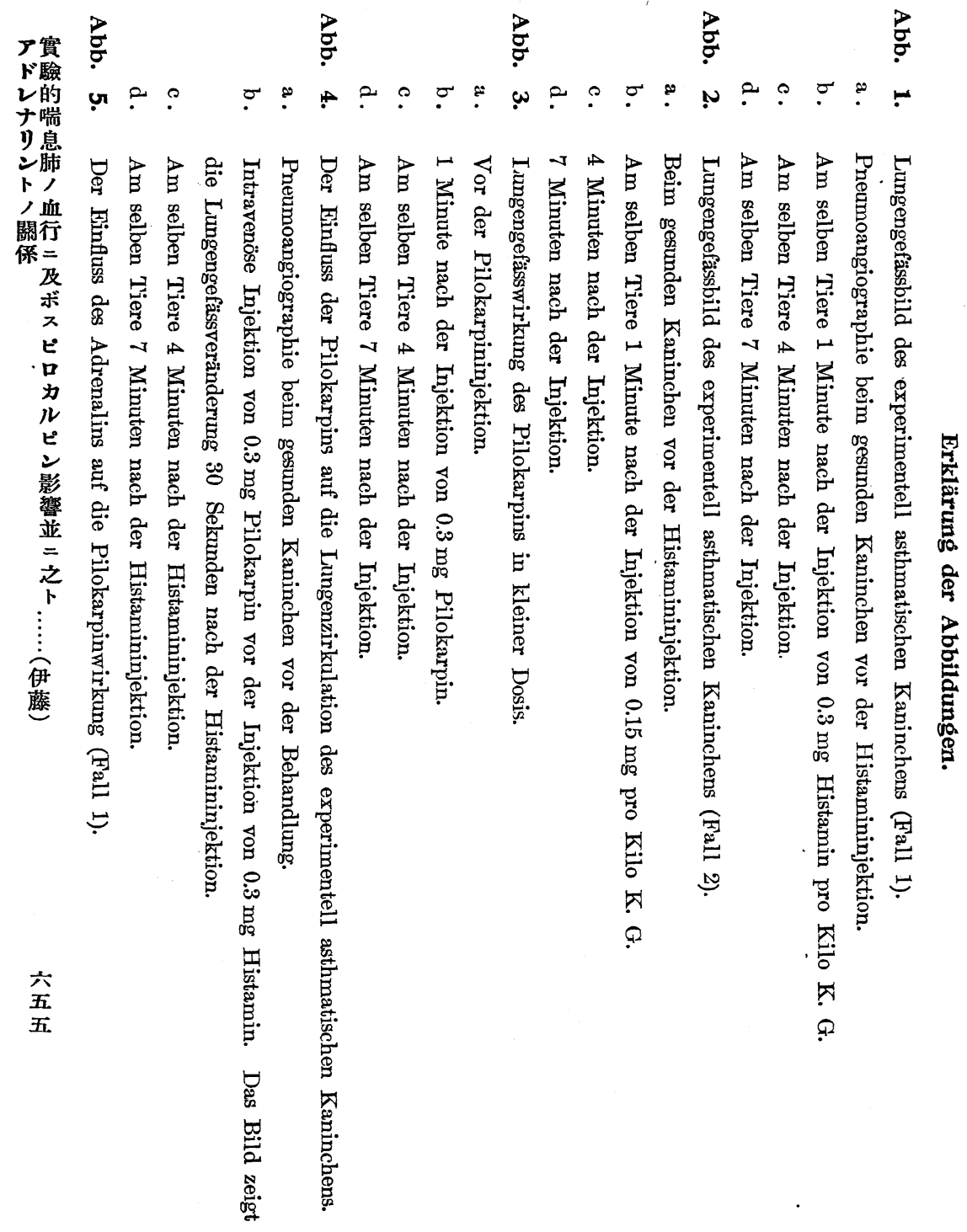




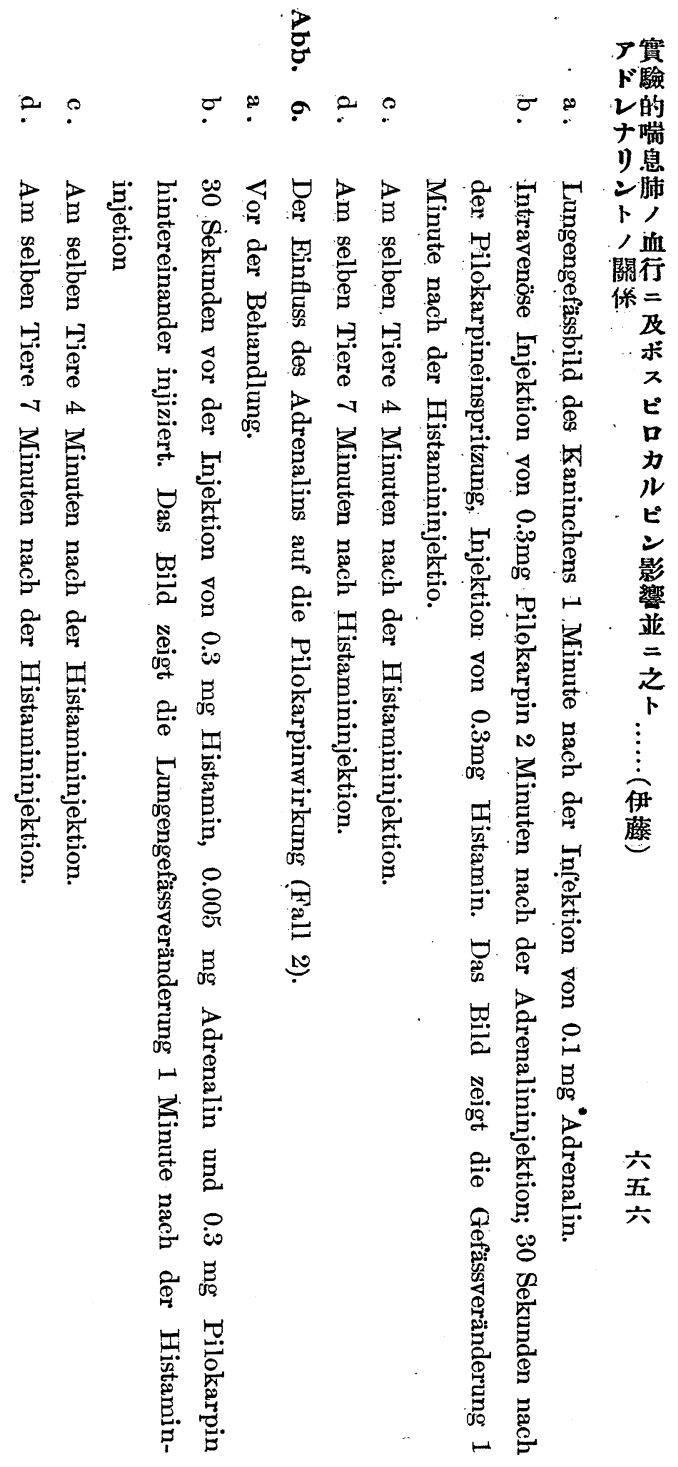


Abb. 1

b.

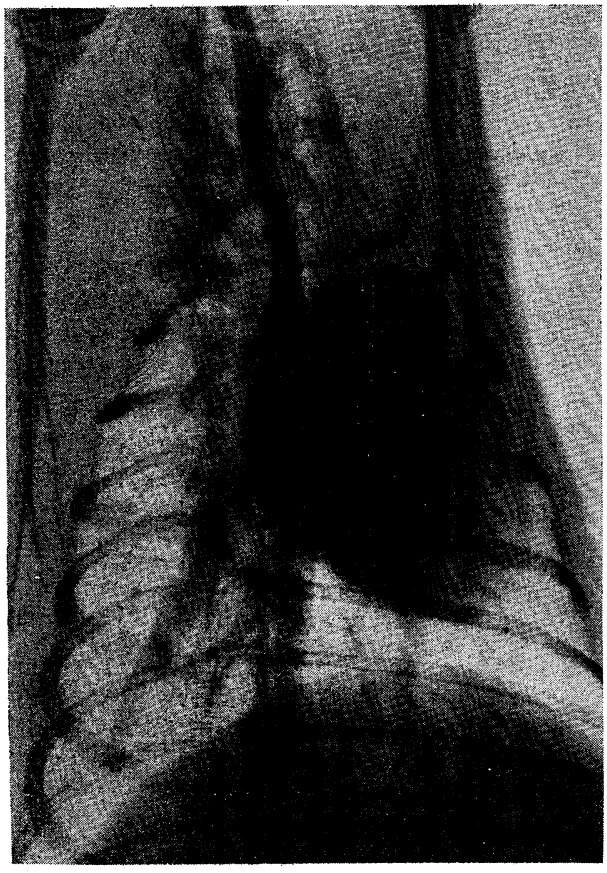

d.

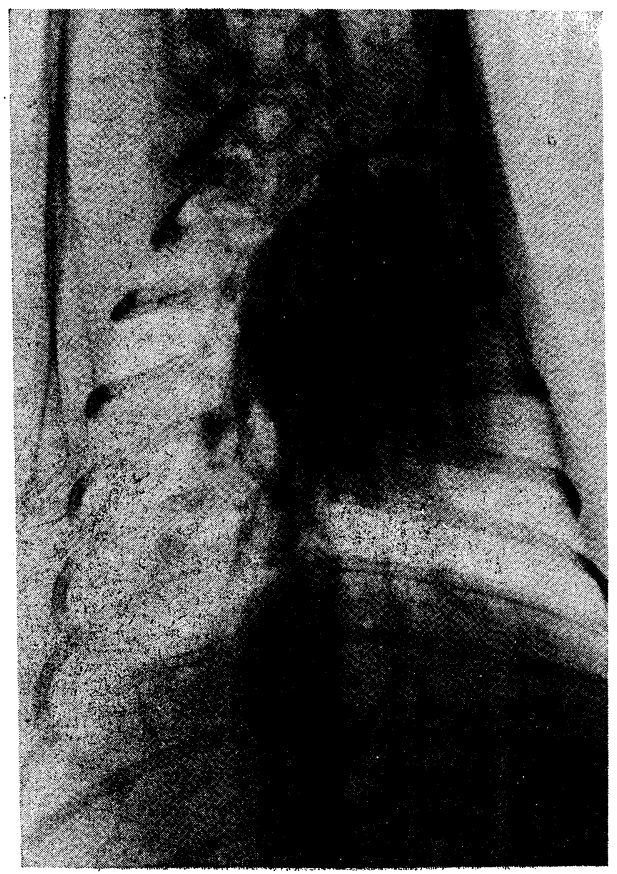

a."

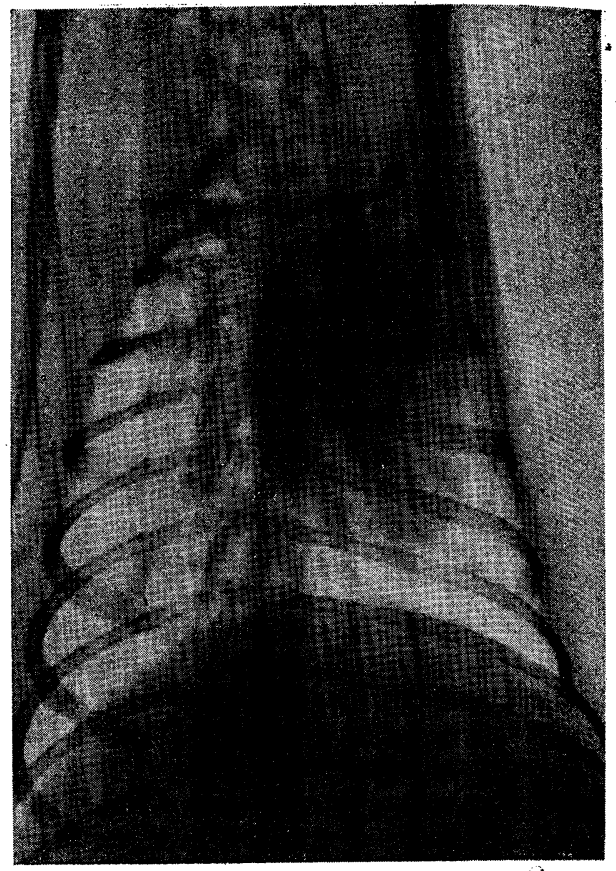

c.

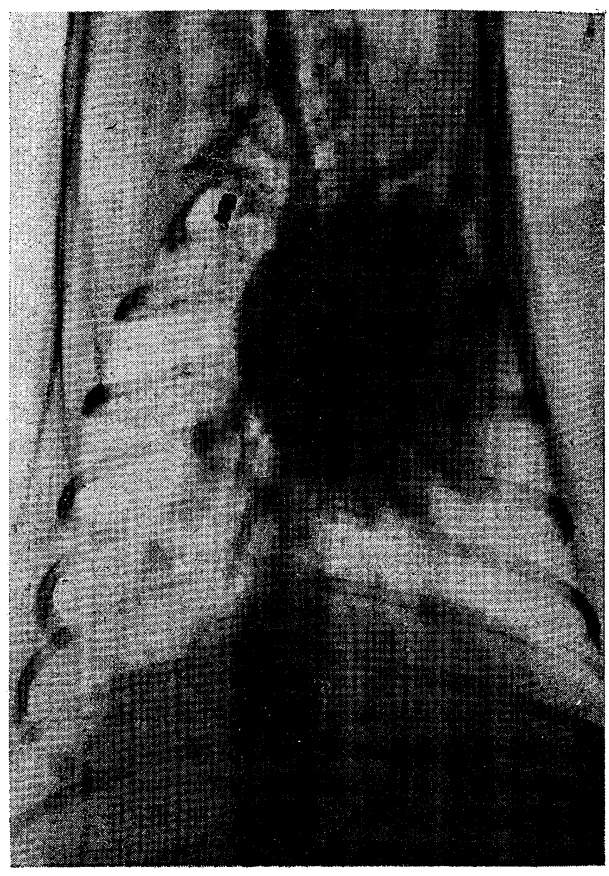


b.

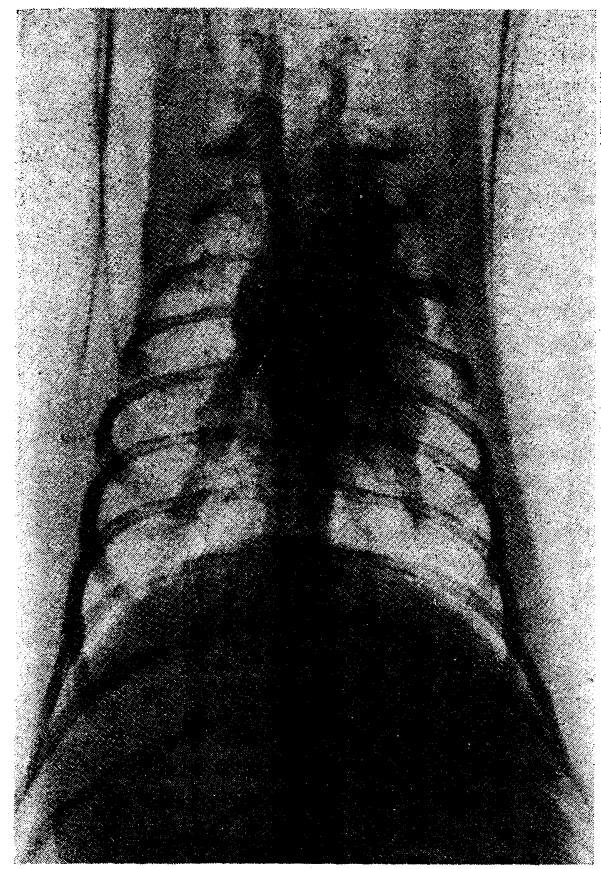

d.

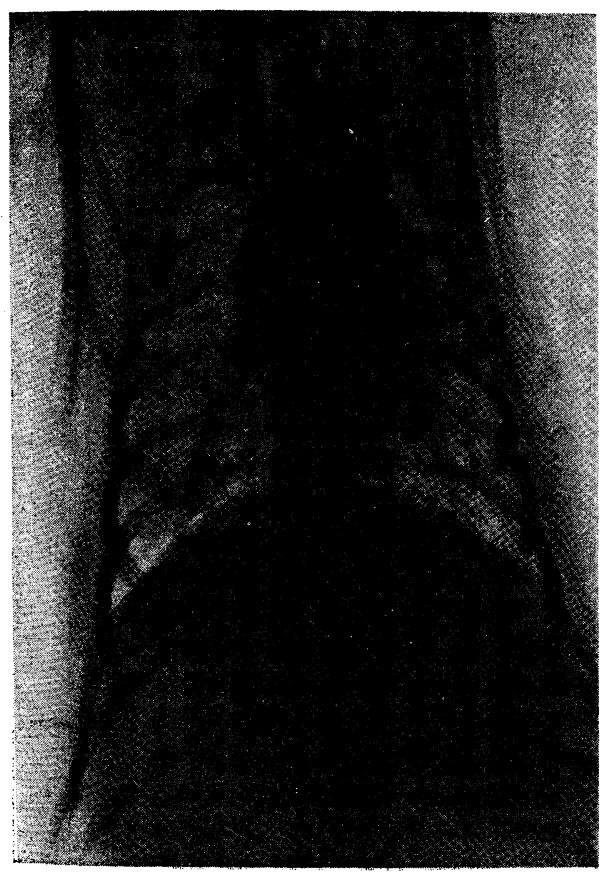

a.

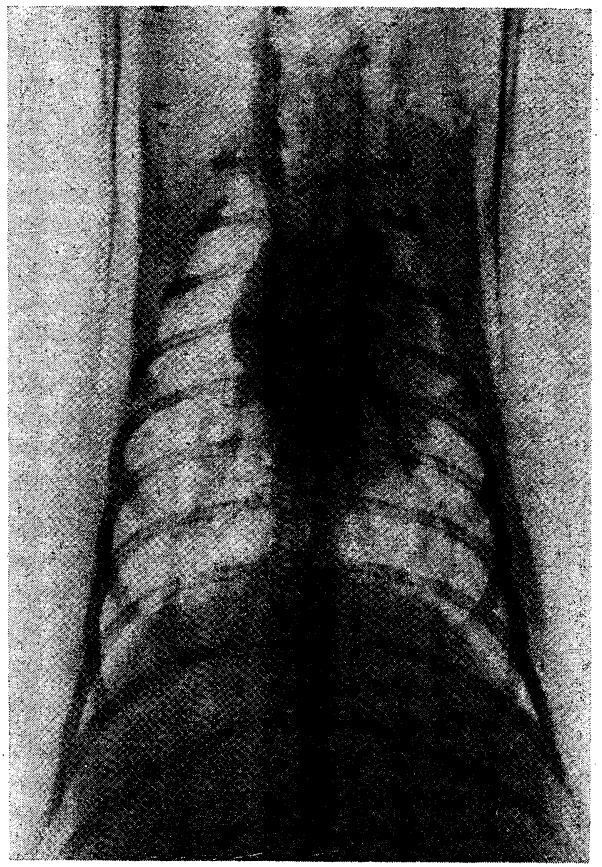

c.

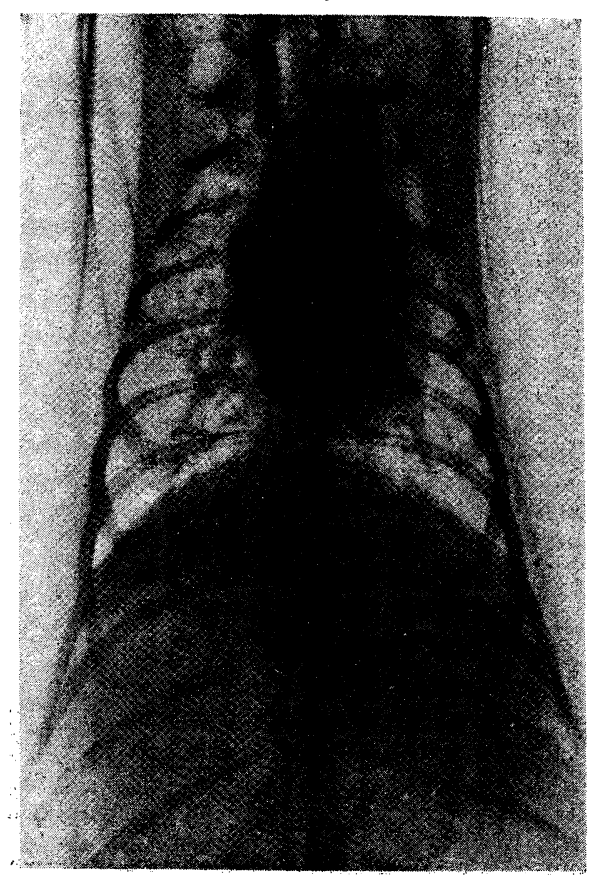


Abb. 3

b.

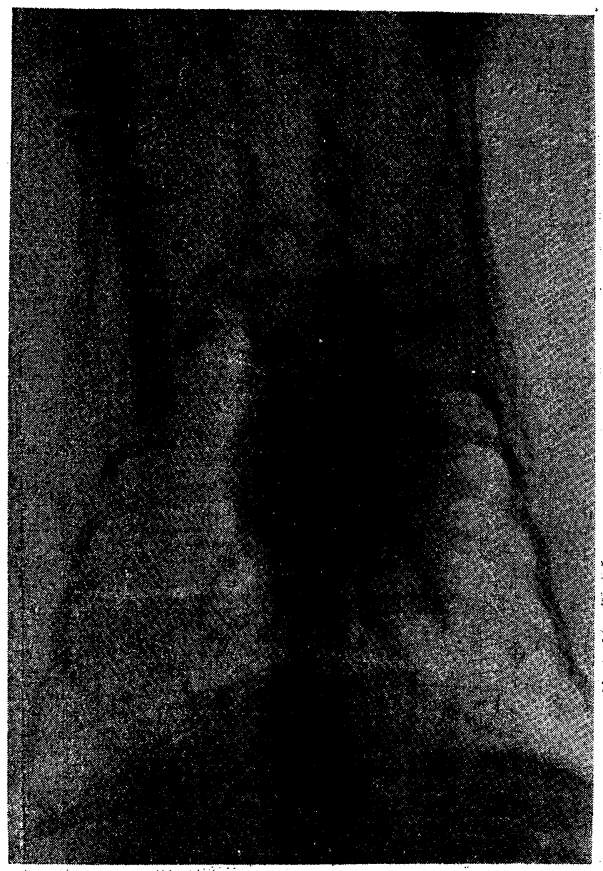

d.

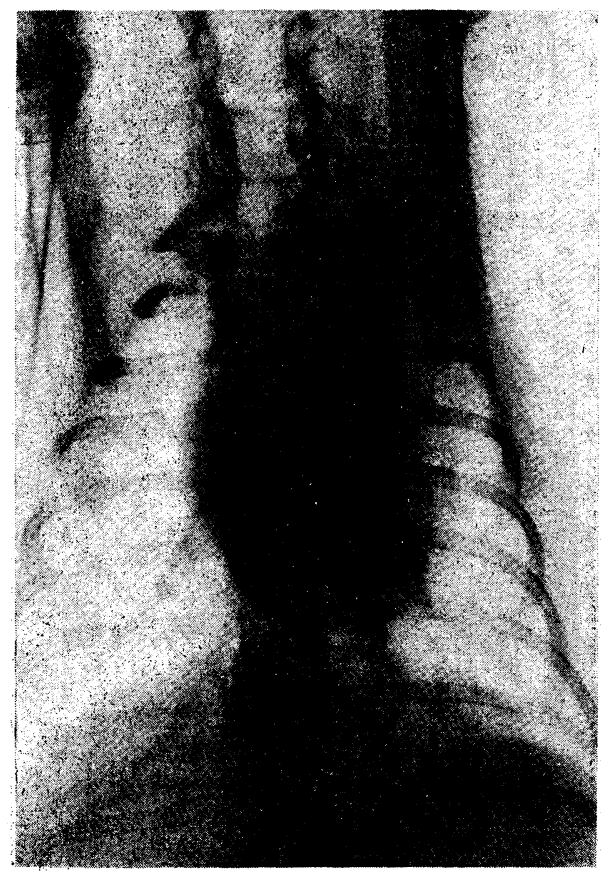

a.

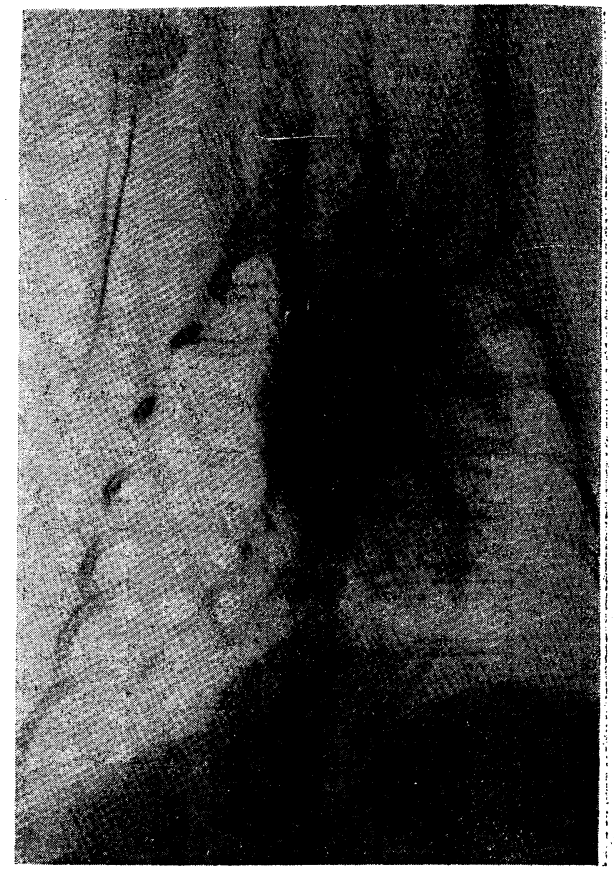

c.

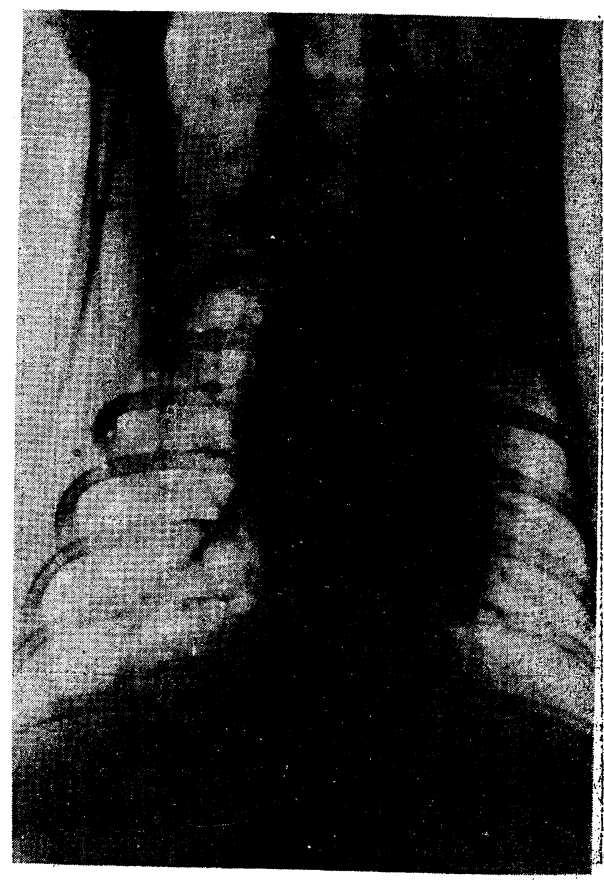


b.

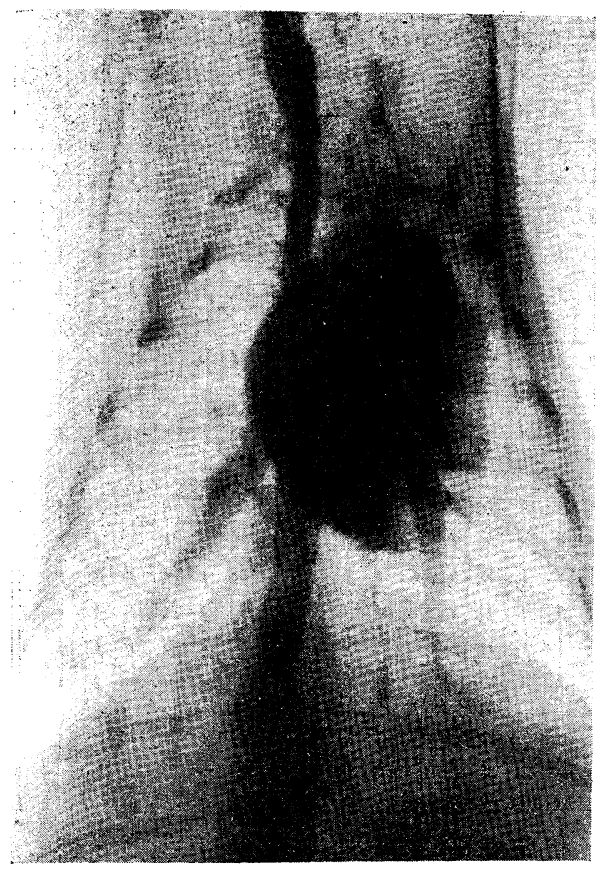

d.

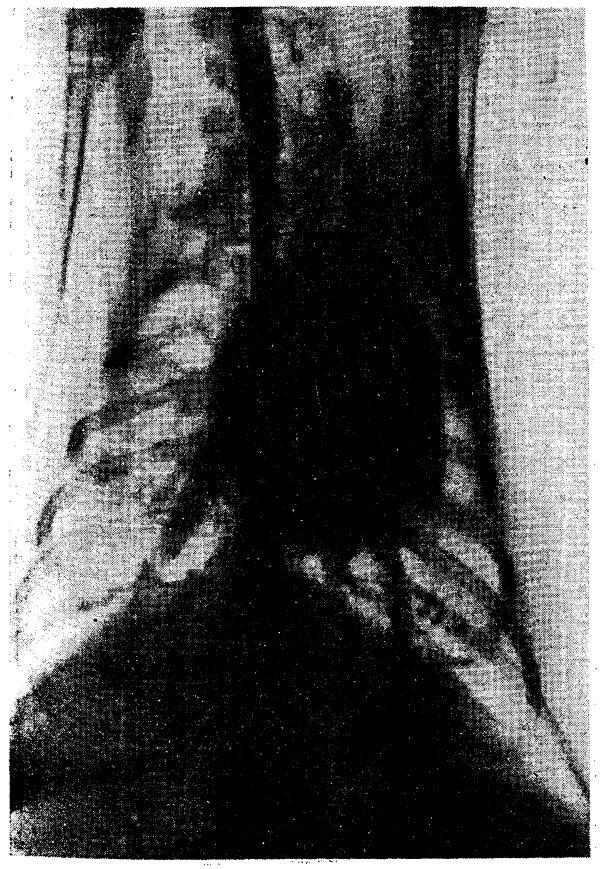

Abb. " 4

a.

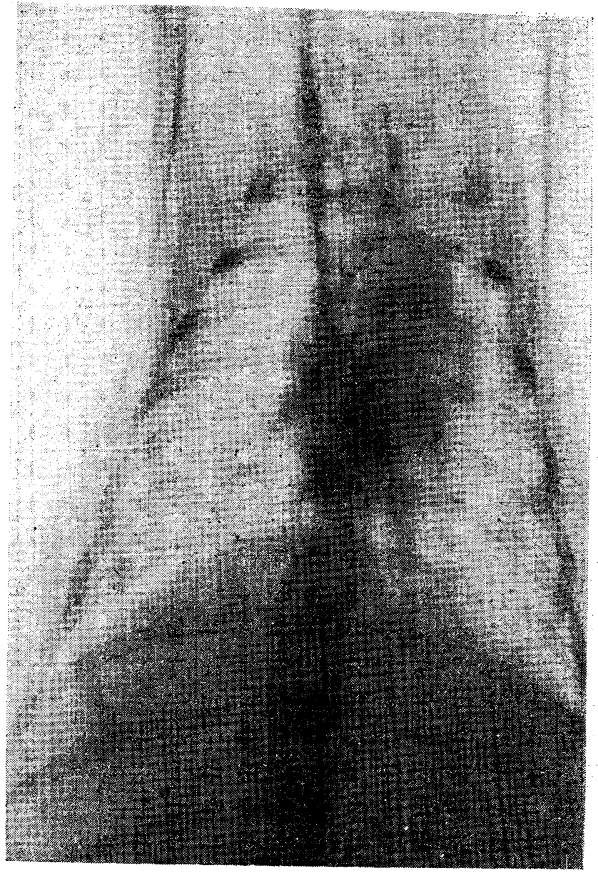

c.

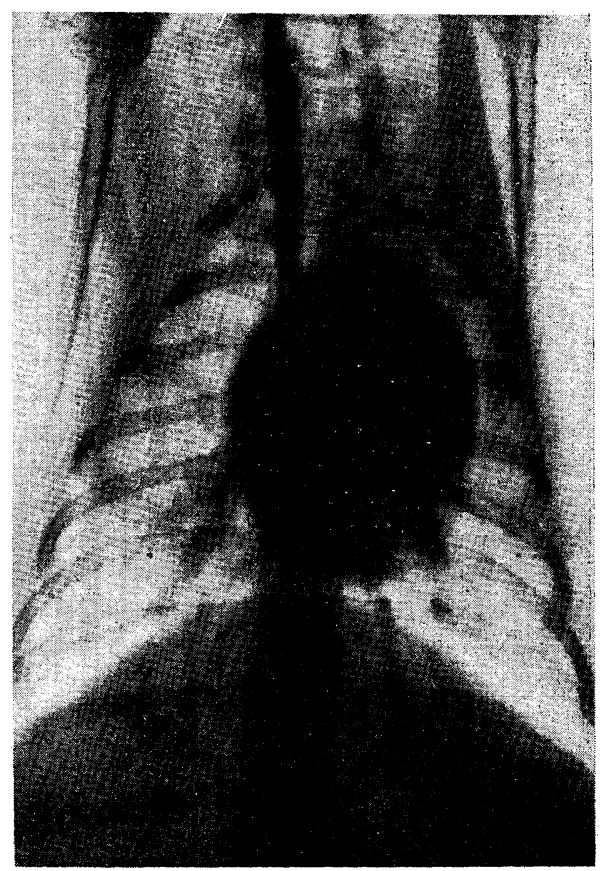


Abb. 5

b.

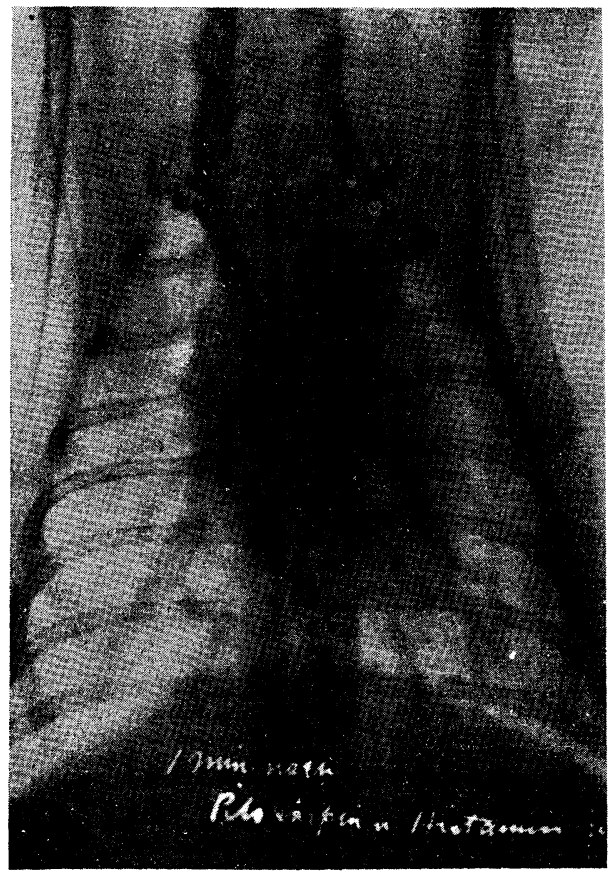

d.

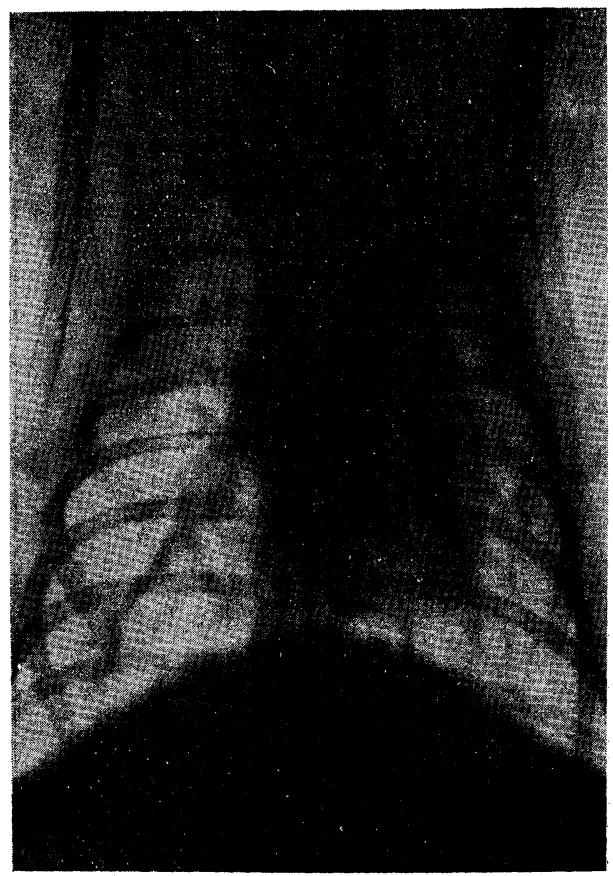

a.

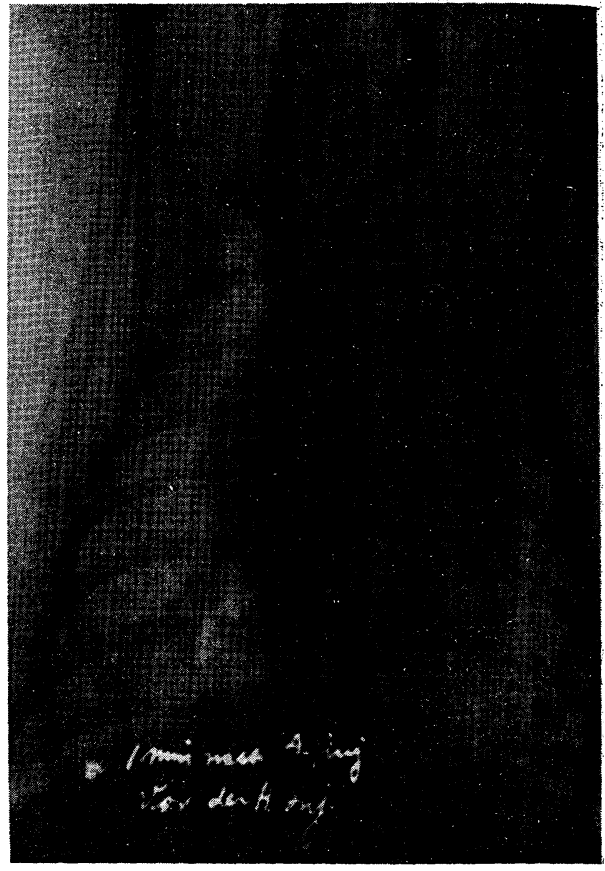

c. 
Abb. 6

b.

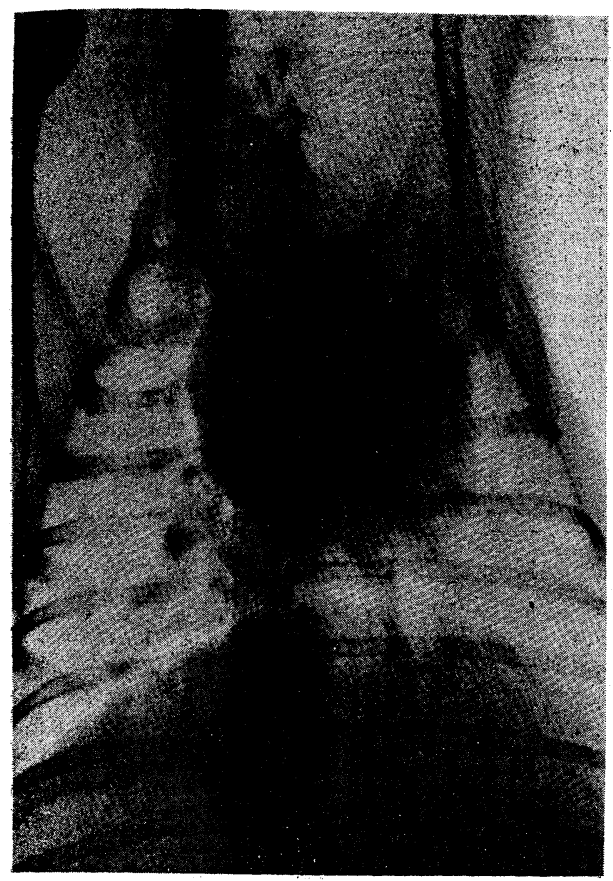

d.

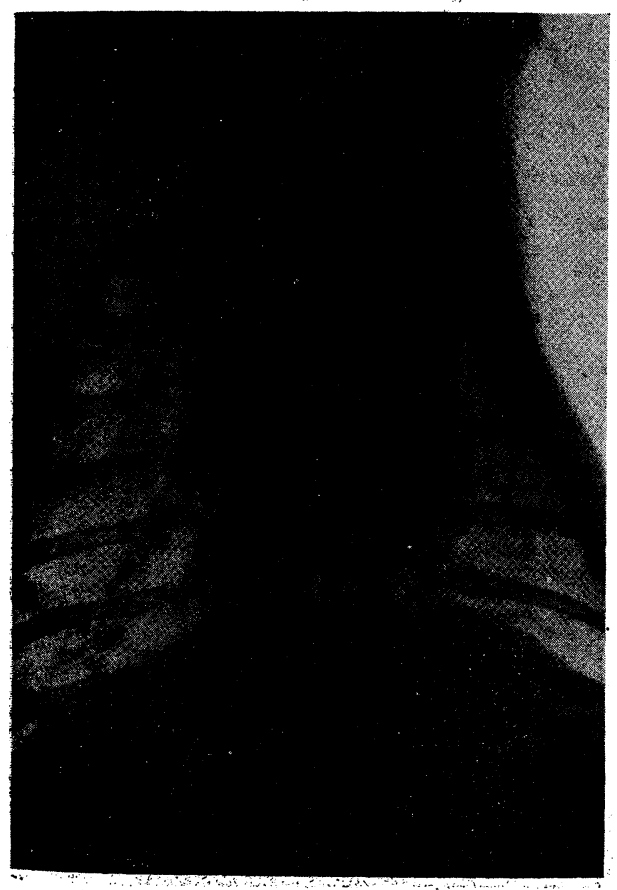

a.

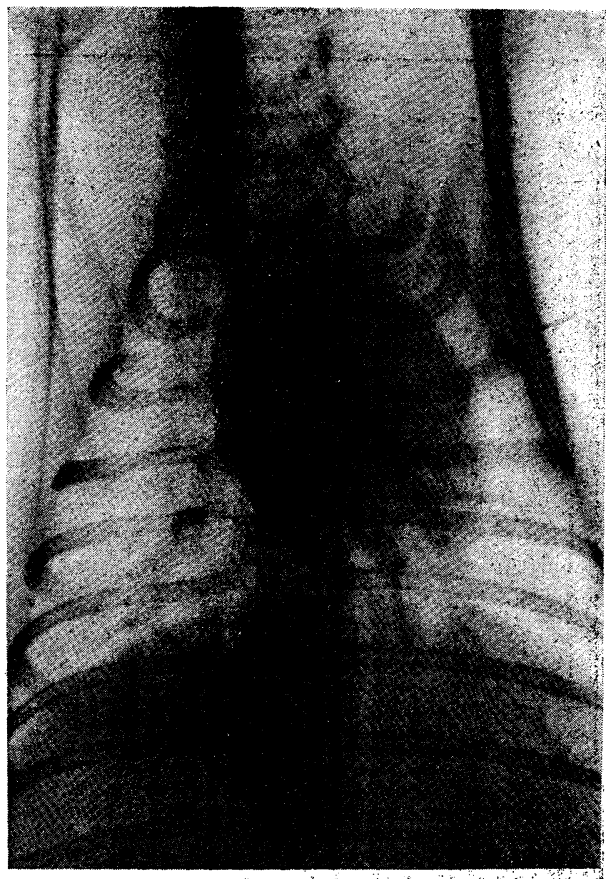

.

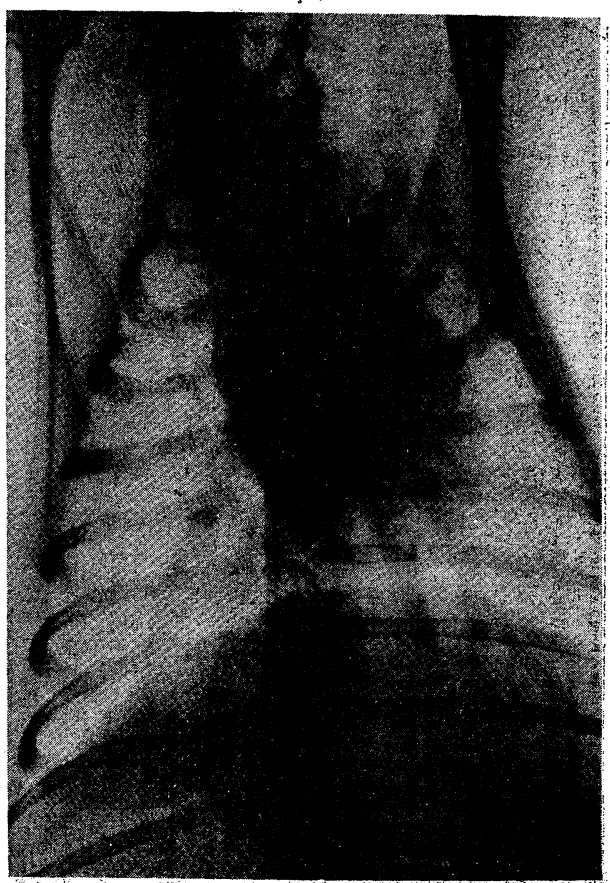


Minuten lang an. Es ist bereits bekannt, dass das. Adrenalin die Lungengefässe direkt kontrahiert. So handelt es sich bei der ebenerwähnten Erweiterung dieser Gefässe um eine sekundäre Erscheinung, zu der es durch die Kontraktion der Splanchnicusgefässe kommt. Die Injektiou von $0.5 \mathrm{mg}$ Papaverin pro Kilo Tier übt keinen nennenswerten Einfluss auf den Lungenkreislauf aus, während auf die Menge von $2.5 \mathrm{mg}$ pro Kilo Tier die Lungengefäss mit Dilatation reagieren. Bei grossen Dosen, z. B. $5.0 \mathrm{mg}$ pro Kilo Tier, sieht man wieder keinen Einfluss. Die bemerkbare Erweiterung ist der direkten Lungengefässwirkung des Papaverins zuzuschreiben.

Die obenberichtete lungengefässerweiternde Wirkung des Adrenalins wird durch Papaverin nicht verstärkt. Diese Tatsache spricht dafür, dass der Erweiterungsmechanismus der beiden Mittel ganz verschiedener Natur ist.

(Autoreferat.)

\section{Über den Einfluss des Pilokarpins auf die Lungenzirkulation des experimenttell asthmatischen Kaninchens und seine Beziehung zum Adrenalin.}

Von

(Aus der I. Med. Klinik der Kaiserl. Univers. zu Kyoto in Japan. Direktor: Prof. Dr. K. Tsuji)

In der vorigen Mitteilung teilte der Verfasser über eine merkwürdige Zirkulationsstörung mit, die er im Röntgenbild der. experimentell asthmatischen Kaninchenlunge entdeckt hatte. In der vorliegenden Mitteilung handelt es sich um die Dauer dieser Zirkulationsstörung.

Nach Einspritzung von $0.15 \mathrm{mg}$ Histamin pro Kilo Tier sieht man als Zeichen der Zirkulationsstörung Erweiterung und Verschattung der A. pulmonalis und des rechten Herzens. Diese Veränderung ist bereits 4 Minuten nach der Injektion wieder verschwunden. 
Injiziert man jedoch $0.3 \mathrm{mg}$ Histamin pro Kilo Tier, so dauert dieses Stauungsbild über 7 Minuten an. Aus diesen Resultaten geht hervor, dass die Histaminwirkung längere Zeit anhält.

Pilokarpin übt in kleiner Dosis auf die Lungenzirkulaton keinen anffallenden Einfluss auf. Nur gewahrt man leichte Abnahme des Pulnonalisstammes, des Aortenbogens und des Herzschattens.

Das vorher mit Pilokarpin behandelte Kaninchen reagiert auf Histamin mit stärkerer Lungenzirkulationsstörung als das nichtbehandelte. Diese stauungsfördernde Wirkung des Pilokarpins wird durch Adrenalin, sowohl in kleiner als auch in grosser Dosis, gehemmt.

(Autoreferat.) 